\title{
(b) CABI
}

กั

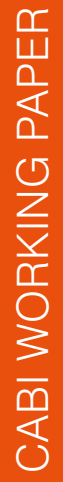

Assessment of the Use and Benefits of the Invasive Species Compendium

April 2021

\section{Authors}

F. Williams, M. Bundi,

S. Hill, E.A. Finch, C. Curry,

F. Mbugua, R. Day,

L. Charles, G. Richards

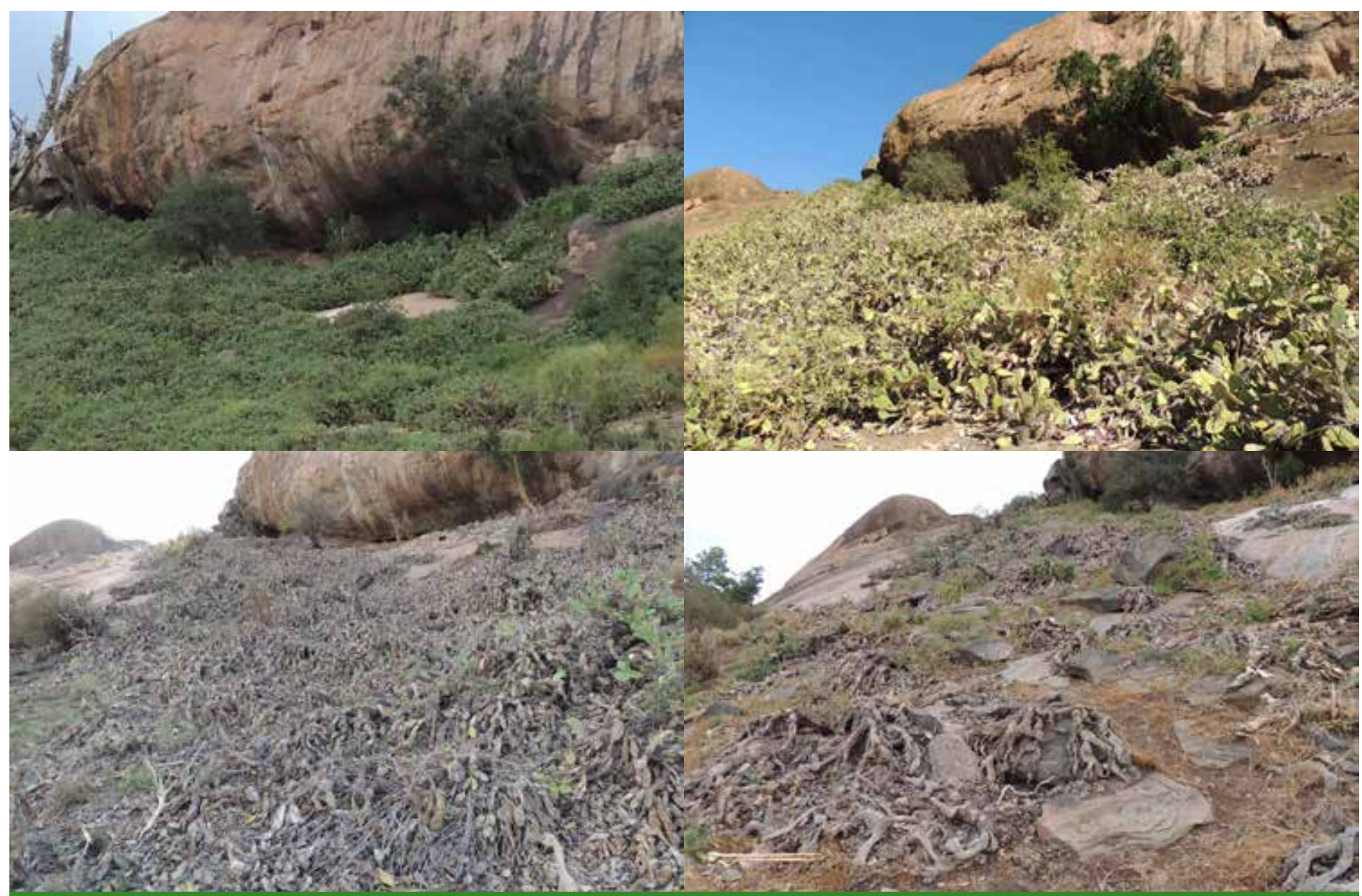




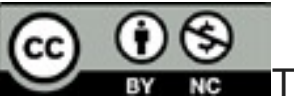

The copyright holder of this work is $\mathrm{CAB}$ International (trading as CABI). It is made available under a Creative Commons Attribution-Non-commercial Licence (CC BY-NC). For further details please refer to http://creativecommons.org/license.

This paper was prepared as part of the Action on Invasives programme. Action on Invasives is supported by the UK Foreign, Commonwealth and Development Office (FCDO) and the Netherlands Directorate General for International Cooperation (DGIS). We thank the survey respondents, including those whose partial responses have been quoted with their permission.

$\mathrm{CABI}$ is an international intergovernmental organisation, and we gratefully acknowledge the core financial support from our member countries (and lead agencies) including the UK (FCDO), China (Chinese Ministry of Agriculture and Rural Affairs), Australia (Australian Centre for International Agricultural Research), Canada (Agriculture and Agri-Food Canada), the Netherlands (DGIS) and Switzerland (Swiss Agency for Development and Cooperation). See http://www.cabi.org/about-cabi/who-we-work-with/key-donors/ for full details.

This CABI Working Paper was internally peer-reviewed. It may be referred to as:

Williams, F., Bundi, M., Hill, S., Finch, E.A., Curry, C., Mbugua, F., Day, R., Charles, L. and Richards, G. (2021) Assessment of the Use and Benefits of the Invasive Species Compendium. CABI Working Paper 20, 45 pp. https://dx.doi.org/10.1079/CABICOMM-628146 (Originally issued April 2021, corrected version issued May 2021)

Frances Williams, CABI, Canary Bird, 673 Limuru Road, Muthaiga, PO Box 633-00621, Nairobi, Kenya

Email: f.williams@cabi.org; ORCID: 0000-0002-6772-0753

Mary Bundi, CABI, Canary Bird, 673 Limuru Road, Muthaiga, PO Box 633-00621, Nairobi, Kenya Email: m.bundi@cabi.org; ORCID: 0000-0002-6431-0273

Simon Hill, CABI, Nosworthy Way, Wallingford, Oxfordshire, OX10 8DE, UK Email: s.hill@cabi.org; ORCID: 0000-0002-5375-2818

Elizabeth A. Finch, CABI, Nosworthy Way, Wallingford, Oxfordshire, OX10 8DE, UK Email: e.finch@cabi.org; ORCID: 0000-0002-7031-5708

Claire Curry, CABI, Nosworthy Way, Wallingford, Oxfordshire, OX10 8DE, UK Email: c.curry@cabi.org; ORCID: 0000-0002-3997-3972

Fredrick Mbugua, CABI, Canary Bird, 673 Limuru Road, Muthaiga, PO Box 633-00621, Nairobi, Kenya

Email: f.mbugua@cabi.org; ORCID: 0000-0002-3168-3671

Roger Day, CABI, Canary Bird, 673 Limuru Road, Muthaiga, PO Box 633-00621, Nairobi, Kenya Email: r.day@cabi.org; ORCID: 0000-0002-4854-7609

Lucinda Charles, CABI, Nosworthy Way, Wallingford, Oxfordshire, OX10 8DE, UK Email: I.charles@cabi.org; ORCID: 0000-0003-1362-1300

Gareth Richards, CABI, Nosworthy Way, Wallingford, Oxfordshire, OX10 8DE, UK Email: g.richards@cabi.org; ORCID: 0000-0002-7303-0812

Cover pictures: Time series photos showing the effect of biocontrol agent on Opuntia stricta in Laikipia, Kenya. (Photos: Arne Witt, CABI) 


\section{Table of contents}

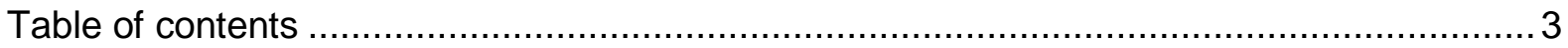

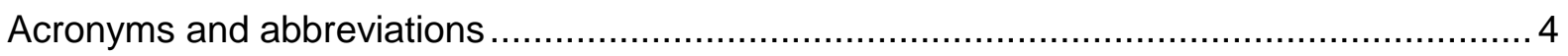

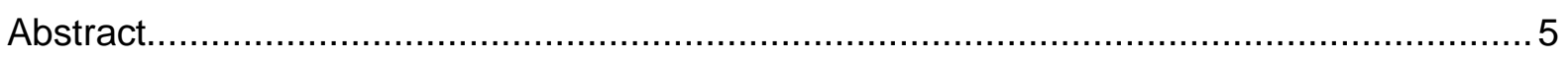

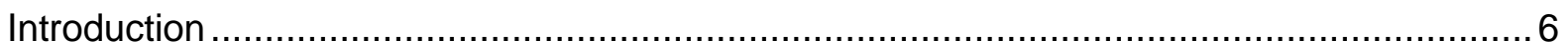

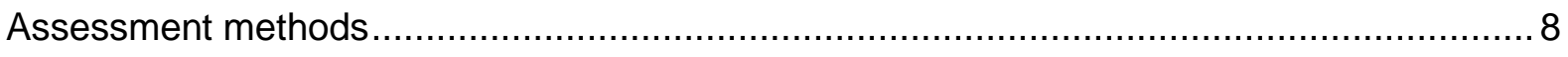

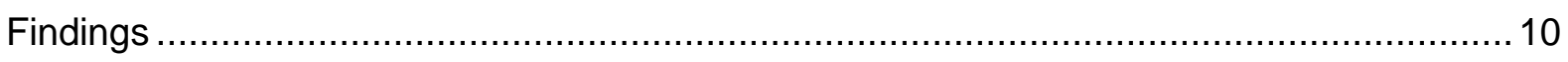

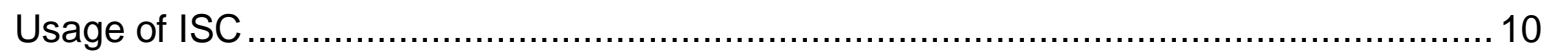

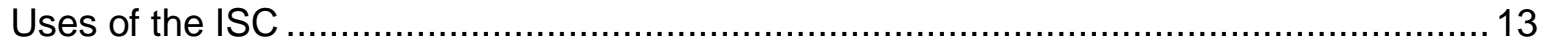

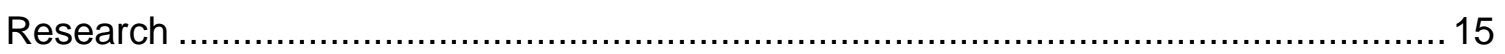

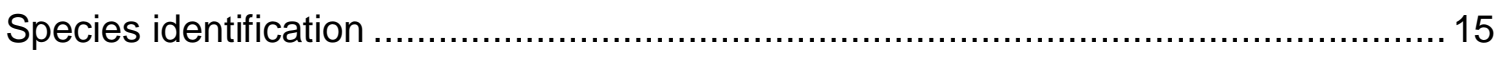

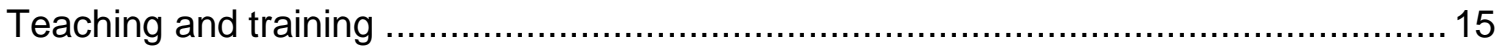

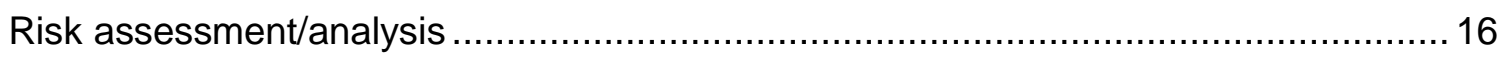

Preparation of information materials, databases and management plans ................... 16

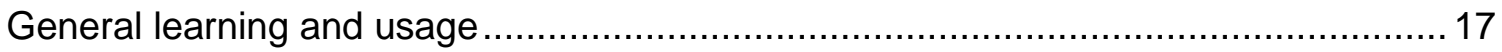

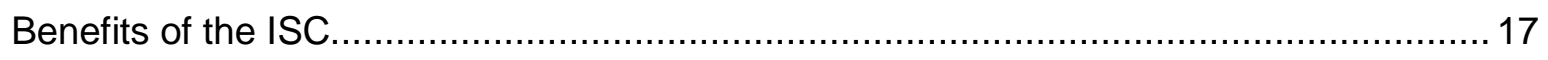

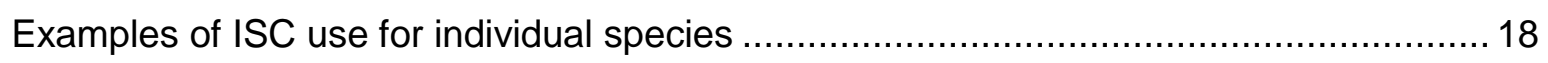

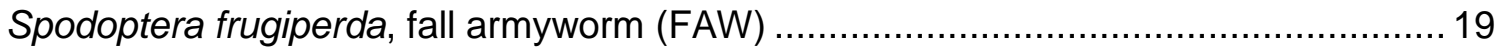

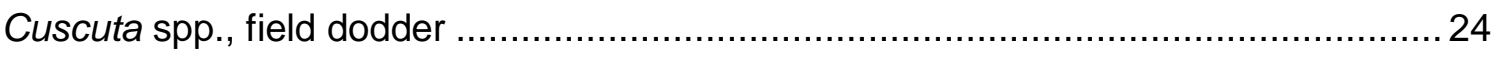

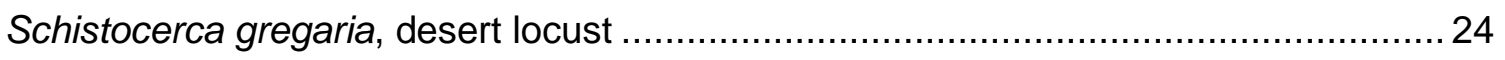

Fusarium oxysporum f. sp. cubense tropical race (TR4) .................................... 27

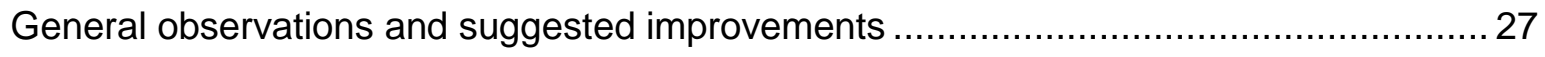

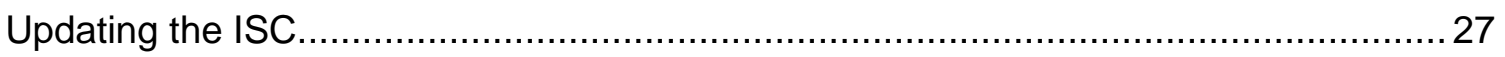

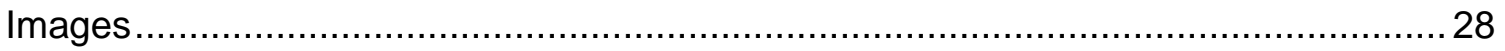

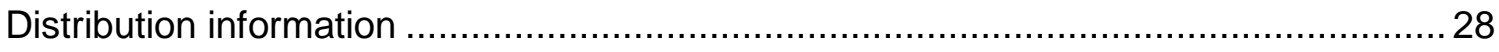

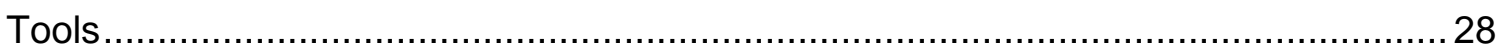

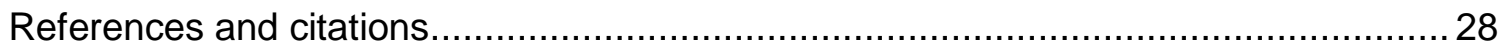

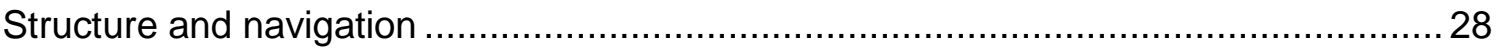

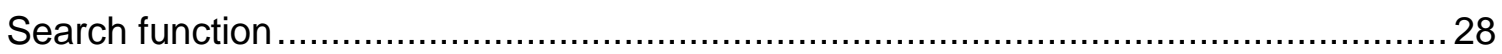

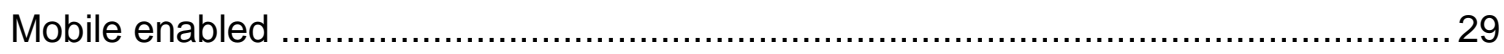

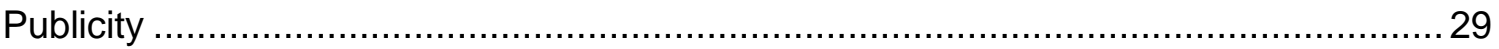

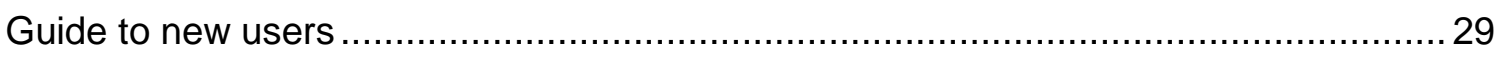

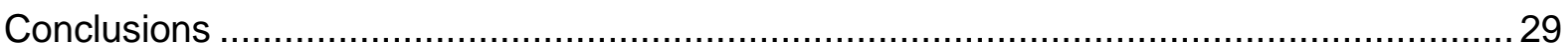

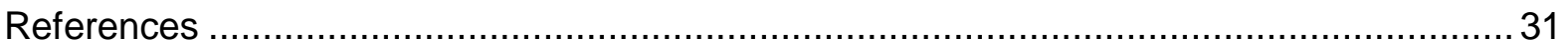

Annex 1: Species mentioned in this report with a link to the relevant ISC datasheet ........... 34

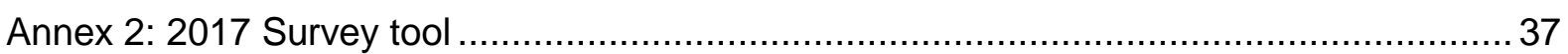

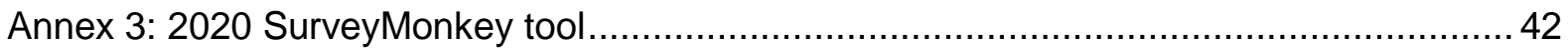

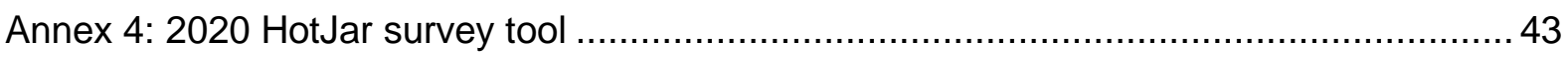




\section{Acronyms and abbreviations}

Aol

API

ASEAN

CAHFSA

CARICOM

CPC

FAO

FAW

GDP

GISD

GISIN

GRIIS

icipe

ICT

IGO

IPPC

ISC

ISSG

IUCN

KEPHIS

NGO

NISIC

PRA

TR4
Action on Invasives (CABI)

Application Programming Interface

Association of Southeast Asian Nations

Caribbean Agricultural Health and Food Safety Agency

Caribbean Community and Common Market

Crop Protection Compendium

Food and Agriculture Organization of the United Nations

Fall armyworm

Gross domestic product

Global Invasive Species Database

Global Invasive Species Information Network

Global Register of Introduced and Invasive Species

International Centre of Insect Physiology and Ecology

Information and communication technology

Inter-governmental organisation

International Plant Protection Convention

Invasive Species Compendium

Invasive Species Specialist Group

International Union for the Conversation of Nature

Kenya Plant Health Inspectorate Service

Non-Governmental Organisation

National Invasive Species Information Center, USA

Pest risk analysis

Fusarium oxysporum f. sp. cubense tropical race 4 


\section{Abstract}

The use of information and communication technology, including e-resources, to deliver information has expanded rapidly in recent years. They have certain advantages including quick access to relevant and current information that may not be available through other means. There are several online resources that provide information about invasive species including the Invasive Species Compendium (ISC). There has been limited work to assess these websites, including whether they provide up-to-date information, the extent of their global coverage, and how users perceive their usefulness. This study assesses such factors for the ISC, analysing usage statistics, data from three user surveys and information from key informant interviews. Findings show that the ISC is highly valued by users, in particular researchers, and that the information is up to date, reliable, and open access, which is of particular value to those working in the Global South. While considerable use of the ISC is to seek out information related to invasive species, it is apparent that other users explore the website to discover information to help manage crop pests and diseases. Key feedback included how users access datasheets within the ISC, and the low level of awareness of the resource. Going forward, it is critical that the ISC can remain as an open access resource, with sufficient funding to ensure it is continuously updated. This will enable researchers in the Global South to continue to access key data and literature, while concentrating resources on fieldwork, pest risk analysis, management and control. 


\section{Introduction}

The use of information and communication technology (ICT) has expanded rapidly in recent years with access to information through desk-top computers, laptops and mobile phones being commonplace now. As a consequence of this rapid expansion of ICTs, e-resources have also developed and changed rapidly in terms of the methods of information delivery. Eresources have been described as services and resources where information is stored electronically and which are accessible through electronic systems and networks (Parthasarathy, 2014; Dhanavandan and Tamizhchelvan, 2012). The term includes a wide variety of different formats and media including CD-ROMs, e-journals and e-books, internet resources and online databases, which may or may not be interactive. Their key role is considered to be in disseminating current and up-to-date information and knowledge that is of value to those using the resources (Parthasarathy, 2014).

As e-resources became more common in the current century, research has followed to assess the advantages and benefits of using such resources. Some research also considered how the e-resources were used, and whether anything can be done to improve usage. Advantages of e-resources, as compared to paper-based information have been identified as:

- Providing quick access to relevant and up-to-date information (Lucky and Chowdhury, 2012; Ademola et al., 2015; Onyango et al., 2016; Guruprasad, 2017) that would take considerably longer to search through and locate the required information in print media. This has enabled researchers to complete and publish papers in less time than when all research used print-based material (Bhat, 2019).

- Providing access to information that was not available in remote areas (Ademola et al., 2015) or was previously only available in an institute that subscribed to the print copy (Ani et al., 2015; Onyango et al., 2016). This was especially a challenge for researchers based in developing countries (Ademola et al., 2015). Remote access means the research is available anytime and anywhere and can be accessed by many users at one time (Parthasarathy, 2014; Guruprasad, 2017).

- Increasing the range of research material accessible to professionals, researchers and students (Onyango et al., 2016; Guruprasad, 2017).

- Saving time of researchers (Pearce and Monck, 2006; Guruprasad, 2017) and speeding up the early stages of research (Bhat, 2019) by reducing the time needed for literature reviews and investigating current research on the topic of interest. This increases research productivity (Ani et al., 2015).

- Increasing the quality of research or project work (Onyango et al., 2016; Guruprasad, 2017) due to access to up-to-date and current research, introducing students to scientific writing, as well as being able to compare research findings with other similar research (Bhat, 2019).

Research by Onyango et al. (2016) found that e-resources have been used for proposal writing, consultancies, professional research and in writing journal papers. They are also used by students to carry out assignments, and prepare for exams. Use of e-resources was considered to have a positive impact on research activities, including proposal submission, research funding and journal submission, demonstrated by increases in numbers of proposals and journal papers submitted, books and papers published and funding received (Manda and Nawe, 2008). 
An example of an e-resource is the Invasive Species Compendium (ISC), which CABI developed and launched in 2012. It is an encyclopaedic resource that brings together a wide range of different types of science-based information to support decision making in invasive species management (CABI, 2020a). This resource is available online for free. It consists of detailed datasheets (see Annex 1 for datasheets referred to in this report) developed by species experts and includes images, distribution maps and links to a bibliographic database. The compendium is aimed at researchers, lecturers and students, resource and environment managers, quarantine and biosecurity officers and practitioners, policy makers, agricultural research centres, extension officers, crop protection and animal health practitioners, weed specialists, and all those involved in prevention and management of invasive species. It aims to support decision making for invasive species management, providing an up-to-date online resource that enables time savings for researchers, as well as an authoritative science-based resource, which can be used to support research and teaching and provide advice. Since 2018, CABl's Action on Invasives (Aol) programme has been supporting and enhancing the ISC, adding several new features and tools. This includes the interactive species distribution maps, Horizon Scanning Tool and species portals on fall armyworm (Spodoptera frugiperda, FAW), Phthorimaea absoluta (syn. Tuta absoluta), parthenium weed (Parthenium hysterophorus) and Fusarium oxysporum f. sp. cubense tropical race 4 (TR4).

There are several other e-resources focusing on providing information on invasive species. INVASIVESNET is a global network of networks on invasive species and aims to create greater understanding and better management of invasive species through a sustainable network, which enables the knowledge exchange of high-quality information and open data on invasive species (International Association for Open Knowledge on Invasive Alien Species, 2020). The network of networks was developed in response to a need for greater coordination and cooperation by invasive species scientists globally (Lucy et al., 2016). Access to information in the network is through paid membership.

The Global Invasive Species Database (GISD) aims to increase public awareness about invasive species, based on knowledge and information provided by species specialists and invasive programmes worldwide. It is free to search the database, which covers all taxonomic groups in all ecosystems. According to their website, they have 800 unique visitors and 50,000 hits per day (IUCN ISSG, 2020a). It has a standard and taxonomic search function, as well as an alphabetical list of all species in the database, with Latin and common names, and a list of countries covered by the database. It is managed by the Invasive Species Specialist Group (ISSG) of the International Union for the Conservation of Nature (IUCN) Species Survival Commission. A search of the database did not reveal any records for $S$. frugiperda, $P$. absoluta or $F$. oxysporum, though it does have a record for $P$. hysterophorus. The species records include description, habitat and geographic ranges, impacts, introduction pathways and dispersal methods, management and biological information. Reviewers and dates of last modifications are included, though a review of approximately 20 of the top 100 species pages indicates that the last updates were made in 2010 or 2011.

ISSG, which is a global network of invasive species experts (Pagad et al., 2015), has also developed, with partners, the Global Register of Introduced and Invasive Species (GRIIS) (IUCN ISSG, 2020b). This website contains inventories of invasive species by country, including data on local names, taxonomy, biological status and environment in which the species occurs. Many of the country pages refer to the ISC as a source, and it is listed as a contributor to GRIIS. 
The Global Invasive Species Information Network (GISIN) was developed in 2014 to share data on invasive species in a standard way (Jarnivick et al., 2015) and provides a global platform and informal network of invasive species experts. It provides similar data and information to the other websites and online databases, and links to many other databases. It has better geographic coverage of the USA than other databases (Jarnivick et al., 2015). Continuous funding to support further development and integration of the network has proved challenging.

There are other invasive species e-resources and websites at country rather than global level such as the National Invasive Species Information Center (NISIC) of the United States Department of Agriculture (USDA, 2020), and the Invasive Species Council of Australia (Invasive Species Council, 2020) provides a number of information resources related to invasive species there. Within the Global South there do not appear to be any specific countrylevel databases online, however, the ASEAN (Association of Southeast Asian Nations) Clearing House Mechanism and ASEAN Centre for Biodiversity (2020) has a database of invasive species in that region, as well as factsheets on individual species. The factsheets provide common names, descriptions and origins for species, as well as their reason for introduction, and the habitats the species invades and impacts. Source references are provided, though no date is given for the last update so it is not possible to tell how current the information is. The website provides a link to the ISC.

There have been few reviews of how these databases and e-resources are viewed by users, whether they provide useful, accurate and current information, though Jarnivick et al. (2015) assessed the challenges and successes of the GISIN. Coughlan et al. (2020) have compared four online invasive species databases that have European coverage, including the ISC. They compared the conformity of information and the information quality of the databases, based on data for 49 species of concern to the European Union. Overall the ISC was ranked the highest of the four databases with significantly greater scores than the other e-resources. The ISC ranked the highest on species information, impact information, source material, control information, but not on distributional information. It is possible this may be due to the stronger focus of the ISC on information for invasive species affecting the Global South rather than European countries.

The assessment by Coughlan et al. (2020) of the ISC and other e-resources related to invasive species focuses on conformity and quality of information, but does not consider whether the information provided is useful to users, or how it is used. It also does not assess whether there are any wider benefits from researchers, policy makers, quarantine officials, lecturers, etc. making use of the ISC data in their work. Therefore, in this study we investigate whether the benefits of using e-resources are seen by ISC users, and how the data informs decisions and actions on the management of invasive species, especially by those users from the Global South.

\section{Assessment methods}

A variety of methods have been used to understand the use and benefits of e-resources. Many researchers have used direct survey methods, interviewing users of the e-resources directly (Dhanavandan and Tamizhchelvan, 2012; Tenopir, 2012; Ademola et al., 2015; Bhat and Ganai, 2017; Bhat, 2019), using descriptive statistics and regression techniques to analysis the data. Others have approached their analysis from an economic point of view, calculating the value of change in transaction costs for researchers due to time saved, productivity 
improvements through higher outputs per given input level (Pearce and Monck, 2006) and the return on investment obtained through the use of library resources (Tenopir, 2012). For this study we used a mixed method approach, collecting both quantitative user data as well as qualitative data through surveys and user interviews. This enables an assessment of the level of use, as well as an understanding of what the ISC is used for by researchers.

The quantitative data, obtained through Google Analytics of the ISC, gives a picture of the level of access of the ISC over time, by subject and by location. Google, through analysis for its targeted advertising, categorises each user into an age and gender bracket, based on previous searches. Google Analytics runs as standard on every page within the ISC and tracks every interaction made by users, although no personal data is captured so users cannot be identified. Users are tracked through cookies, and each user access creates a session and every interaction with the ISC pages in each session is tracked and recorded. In addition to this standard tracking, CABI has set up bespoke data points and tracking related to numbers of downloads of datasheets, etc. All these data, including the age and gender categorisation, are captured within a database, which has a cloud-based user interface that allows CABI to explore the data, segment and filter it. This interface also enables the creation of visual reports. A number of different visual reports were generated during September and October 2020 to understand use of the ISC.

Three online surveys have also been carried out. In 2016, before the launch of CABl's Aol programme, a self-selected user survey was carried out through SurveyMonkey (https://www.surveymonkey.com). It ran between November 2016 and February 2017, through a link on the ISC home page and as a posting on the Aliens-L (the mailing list of the ISSG) (Survey tool is in Annex 2). It focused on finding user requirements on the content and functionality of the ISC, and this, together with other market research, resulted in the updating of priority datasets and the development of a number of the tools which are included in the ISC (e.g. the Horizon Scanning Tool and interactive species distribution maps), and also the separately available Pest Risk Analysis Tool.

In 2020, an online survey on SurveyMonkey (survey tool is in Annex 3) was designed with a focus on obtaining qualitative information about how the ISC is being used. It had a set of seven questions, three of which asked respondents to provide information on: (i) whether they had used or use information from the ISC, and ways in which they have used, or are using the information; (ii) ways in which they are using, or have used the information from the ISC to inform decisions, or actions around managing invasive species; and (iii) general feedback on usefulness of information on the ISC, or challenges experienced in using the ISC. The SurveyMonkey was shared via WhatsApp with members of two groups: the Entomological Society of Kenya, with 216 members drawn from policy, academia, research, etc., and the Kenya Fall Armyworm taskforce. The SurveyMonkey link was shared with respondents on the 3 April 2020 and data pulled for analysis on 20 April 2020. Follow-up key informant interviews were carried out to elicit specific examples of use.

A further online survey was carried out between 9 September and 2 October 2020, through placing a HotJar survey on the ISC website (survey tool is in Annex 4). This short (four question) survey collected information on how ISC visitors used the information they had obtained from the website, and gathered detailed examples of these uses. These data were also used for follow up on specific stories of use, through email and online key informant interviews. 


\section{Findings}

\section{Usage of ISC}

Since January 2019, there have been 3.3 million users of the ISC (52.8\% women), visiting nearly 5 million times. It is difficult to obtain usage numbers for other free online compendia, although the GISD website provides figures of 800 unique visitors per day. This equates to approximately 508,000 visitors in total, compared to the 3.3 million users of the ISC over the same January 2019 to September 2020 period (Fig. 1).

These usage numbers compare favourably with use of the ISC before the Aol programme, when average user per day was less than 5,000 (the green line in Fig. 2), increasing to approximately 7,000 to 10,000 users per day. However, this overview excludes the period from early March to early July $2019,{ }^{1}$ when the search engine optimisation was not working, and there was a noticeable decrease in traffic driven to the ISC site, through search engines such as Google.

Users have predominately been based in Asia (38.29\%) and the Americas (30.65\%), with most users from the USA (Table 1). In the Global South, India and the Philippines have high usage numbers, followed by Indonesia, Nigeria, Malaysia and Pakistan.

However, if the number of users per country (top 20 countries) is considered as a proportion of the amount of money a country spends on research and development, it can be seen that use of the ISC is dominated by countries from the Global South (Fig. 3). The Philippines, Nigeria and Pakistan use the ISC the most as a proportion of how much of their countries' gross domestic product (GDP) is spent on research and development, indicating that in countries with lower research funding, the ISC is a relatively more valuable resource.

\footnotetext{
${ }^{1}$ Dates of non-functioning of search engine optimisation were 5 March-30 April, and early May-9 July 2019. A temporary fix was in place between 30 April and early May 2019.
} 


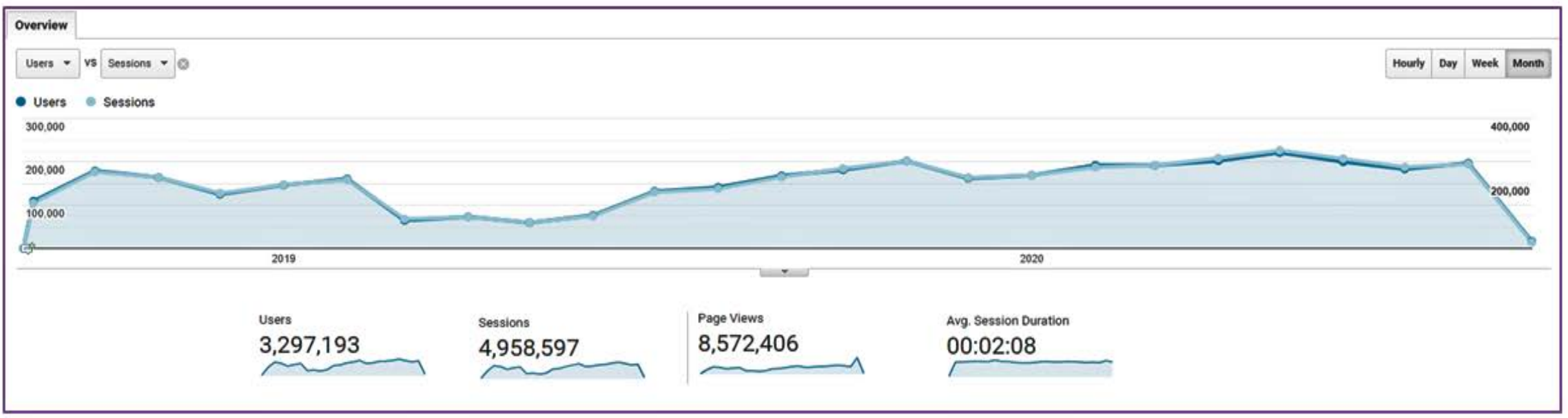

Fig. 1. Number of visits/users and sessions to the ISC, January 2019 to September 2020. Source: Google Analytics.

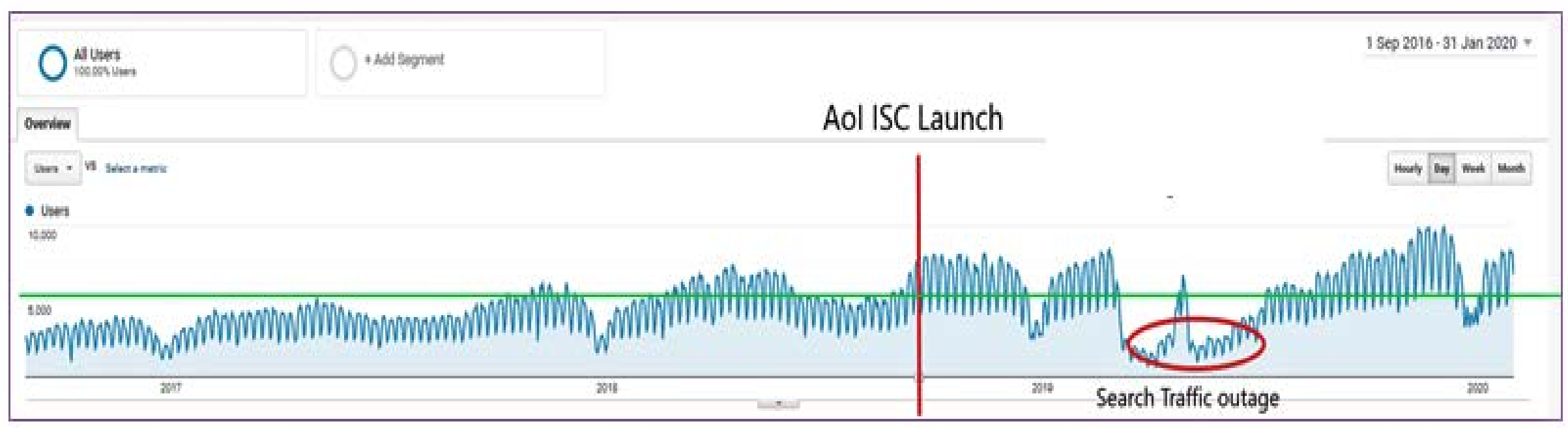

Fig. 2. Usage of ISC before and after Aol programme. Source: Google Analytics. 
Table 1. Location of ISC users (October 2018 to September 2020). Source: Google Analytics.

\begin{tabular}{lll}
\hline Country & Users & Sessions \\
\hline USA & $724,210(21.8 \%)$ & $920,265(18.7 \%)$ \\
India & $490,644(14.8 \%)$ & $719,001(14.5 \%)$ \\
Philippines & $214,540(6.5 \%)$ & $307,637(6.2 \%)$ \\
UK & $147,603(4.4 \%)$ & $217,050(4.4 \%)$ \\
Australia & $138,315(4.2 \%)$ & $203,161(4.1 \%)$ \\
Canada & $100,709(3.0 \%)$ & $128,631(2.8 \%)$ \\
Indonesia & $83,428(2.5 \%)$ & $146,400(3.0 \%)$ \\
Nigeria & $77,835(2.3 \%)$ & $110,082(2.2 \%)$ \\
Malaysia & $67,343(2.0 \%)$ & $118,633(2.4 \%)$ \\
Pakistan & $54,354(1.6 \%)$ & $84,579(1.7 \%)$ \\
\hline
\end{tabular}

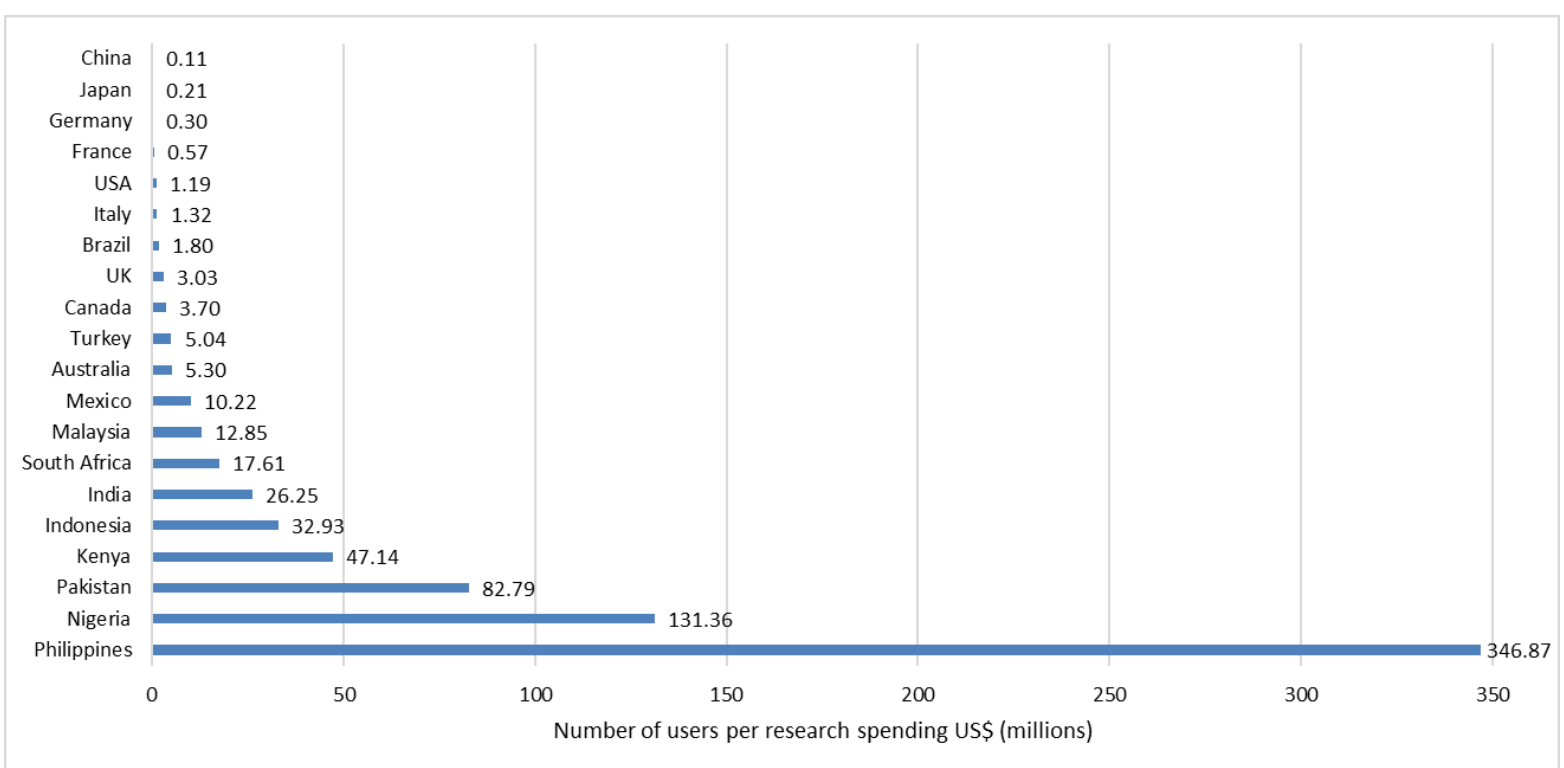

Fig. 3. Number of users of ISC as a proportion of country's spending on research. Sources: Google Analytics; GDP per country: https://data.worldbank.org/indicator/NY.GDP.MKTP.CD; research and development spending as a percentage of GDP per country: https://data.worldbank.org/indicator/GB.XPD.RSDV.GD.ZS. Accessed 18 Nov 2020.

The 2017 survey with 204 respondents, provided information on types of users with most users classing themselves as researchers (31.9\%), and $13.7 \%$ of respondents being students (e.g. MSc, BSc). Other users included risk assessors (9.8\%), land managers (7.8\%), plant protection officers (6.9\%) and lecturers and teachers (4.9\%). Other respondents included a quarantine officer, a federal regulator and an export certification specialist (one respondent each). Nearly $55 \%$ of respondents worked either for government or a university. The number 
of researchers may be a reflection of the membership of the Aliens-L, but given research is the top reason for use in all the surveys conducted, it does not appear to have a large influence on the results about types of users.

\section{Uses of the ISC}

Both the 2017 SurveyMonkey and the 2020 HotJar surveys asked respondents about their main uses of the ISC, while the HotJar 2020 survey also asked respondents about the benefits of using the ISC. The surveys categorised uses in different ways (Figs 4 and 5), with more detailed categories being used in the 2017 survey. However, despite these differences, both surveys indicated that research and identification of species were the top uses of the ISC by survey respondents. Other frequent uses included policy development, awareness raising, management and risk assessment/analysis. Other users commented that their use was for subjects including habitat survey, biosecurity work, regulatory action, agronomic advice, farming including planting decisions, writing and editing articles and manuscripts and new product development research.

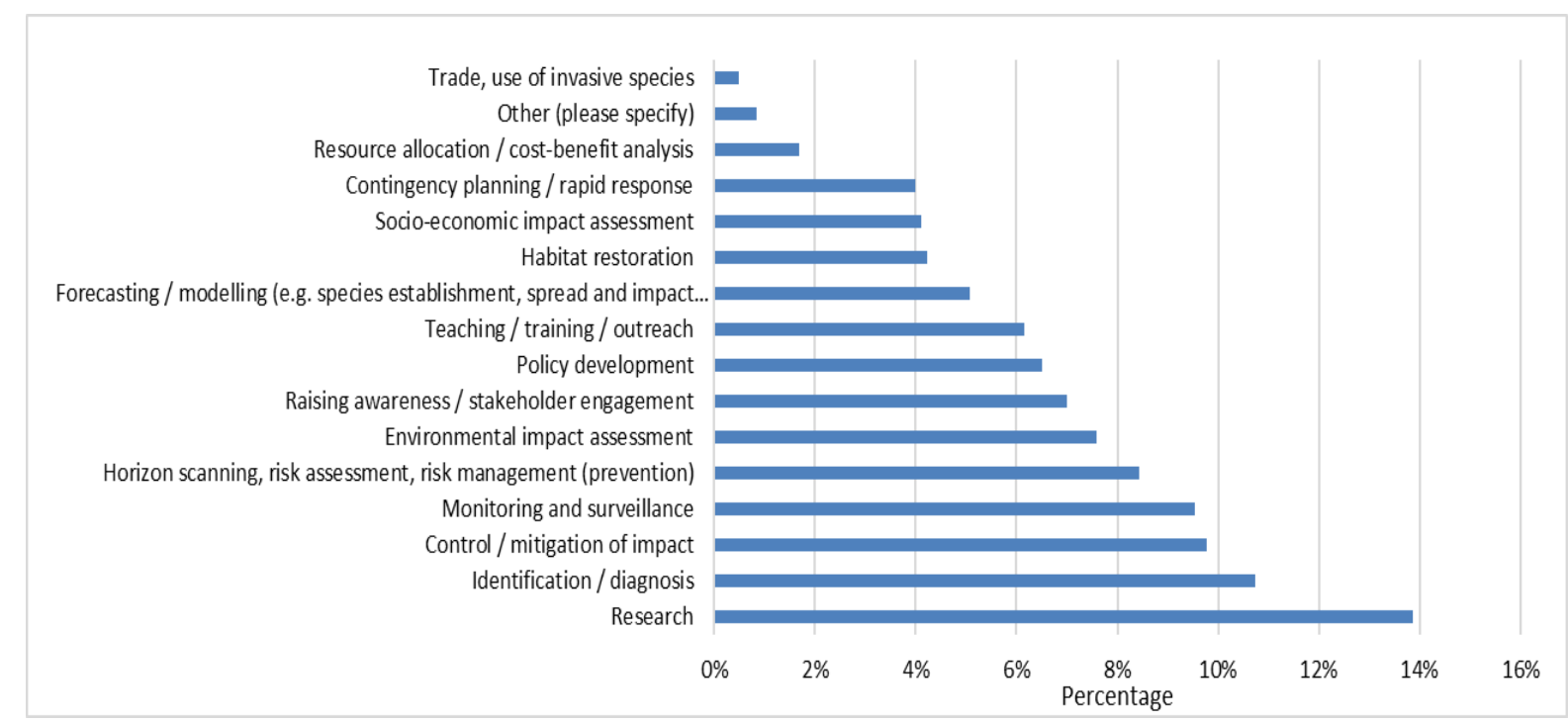

Fig. 4. Uses of ISC and its data (worldwide). Source: 2017 SurveyMonkey survey.

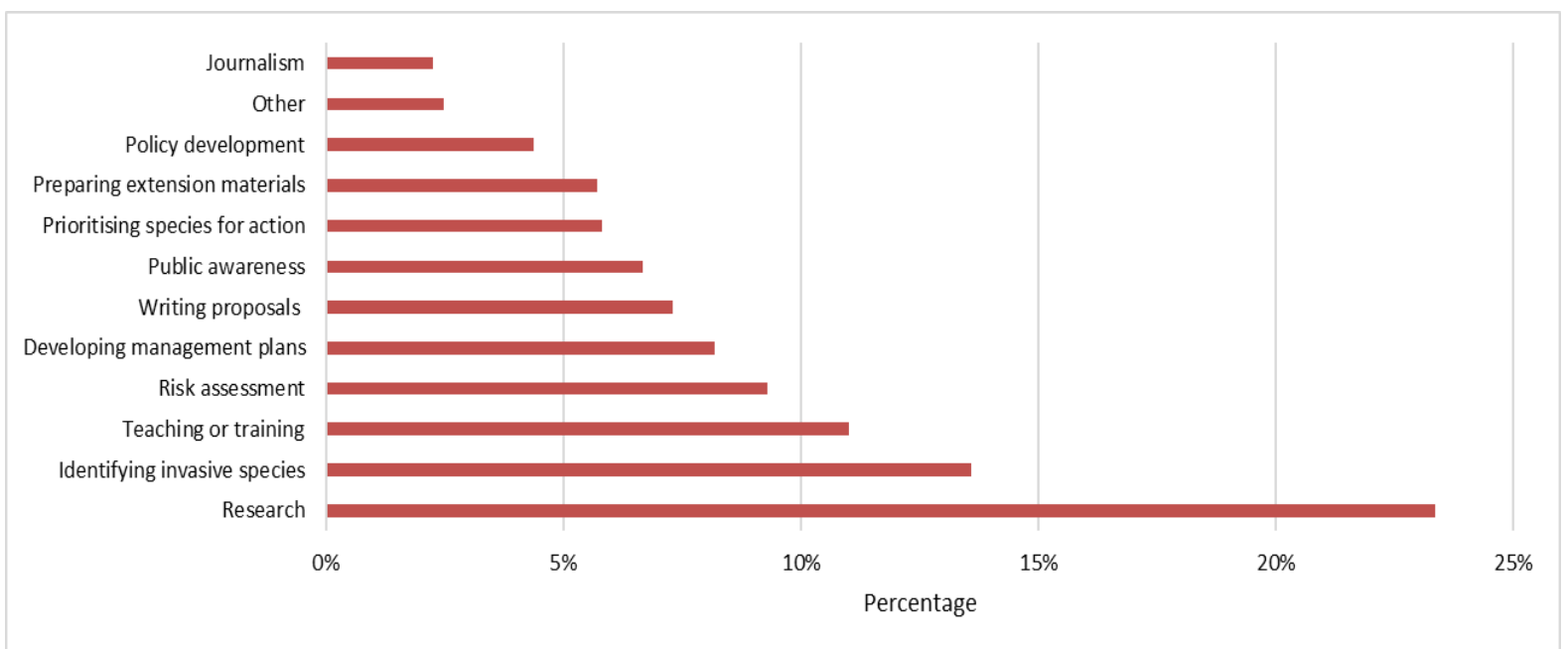

Fig. 5. Uses of ISC and its data (worldwide). Source: 2020 HotJar survey. 
Further analysis indicated the same pattern when just considering the 2020 HotJar survey responses from the Global South (Fig. 6). Use of the ISC for more practical actions (developing management plans, risk assessment, preparing extension materials, prioritising species for action, and policy development) was noted by $32.7 \%$ of respondents.

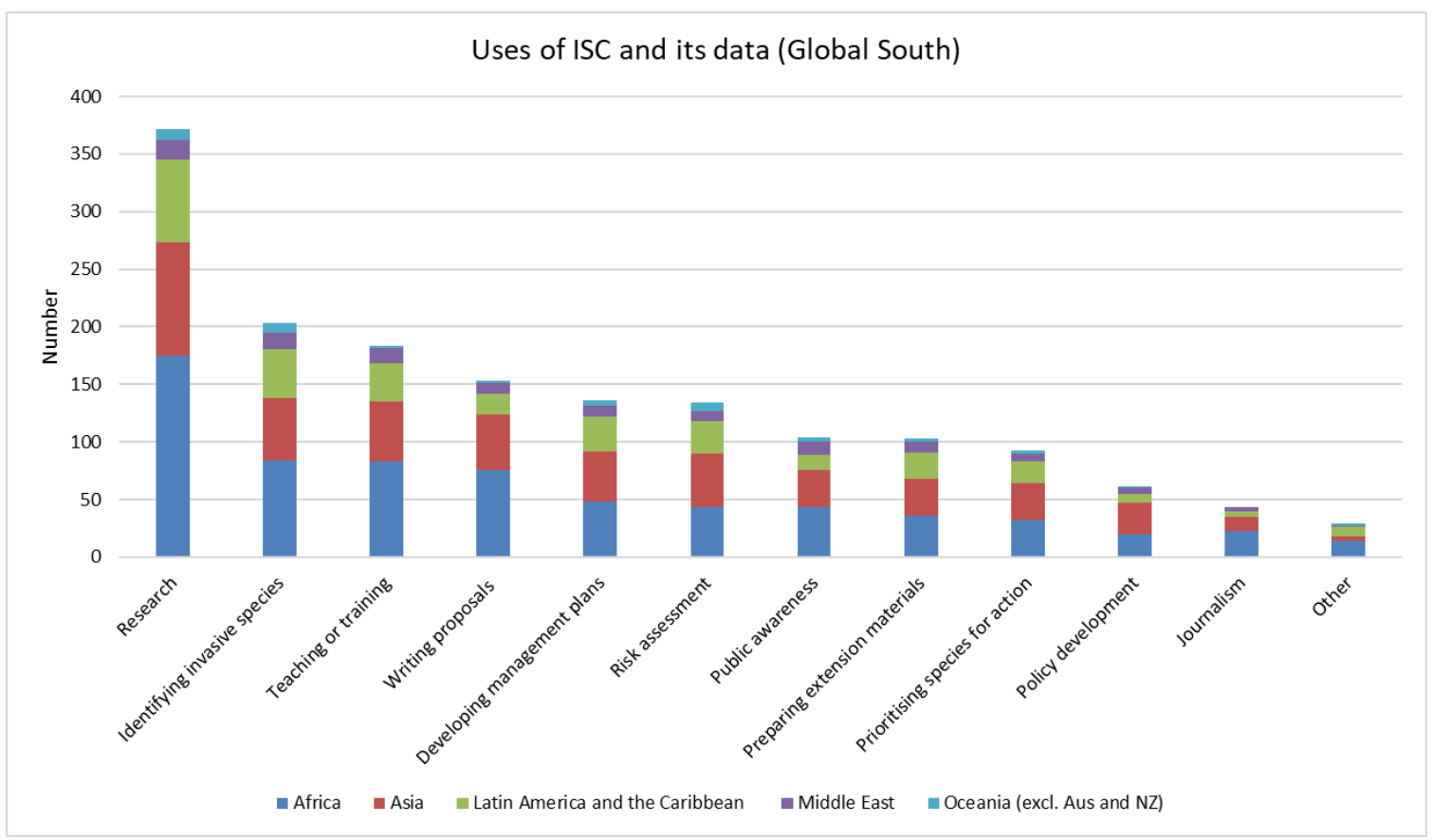

Fig. 6. Uses of the ISC. Source: 2020 HotJar survey.

Follow-up interviews based on both 2020 surveys elicited further details on how the ISC is being used. Key areas included the provision of information, use of this information in research, as well as species identification, management and teaching students and training (Fig. 7).

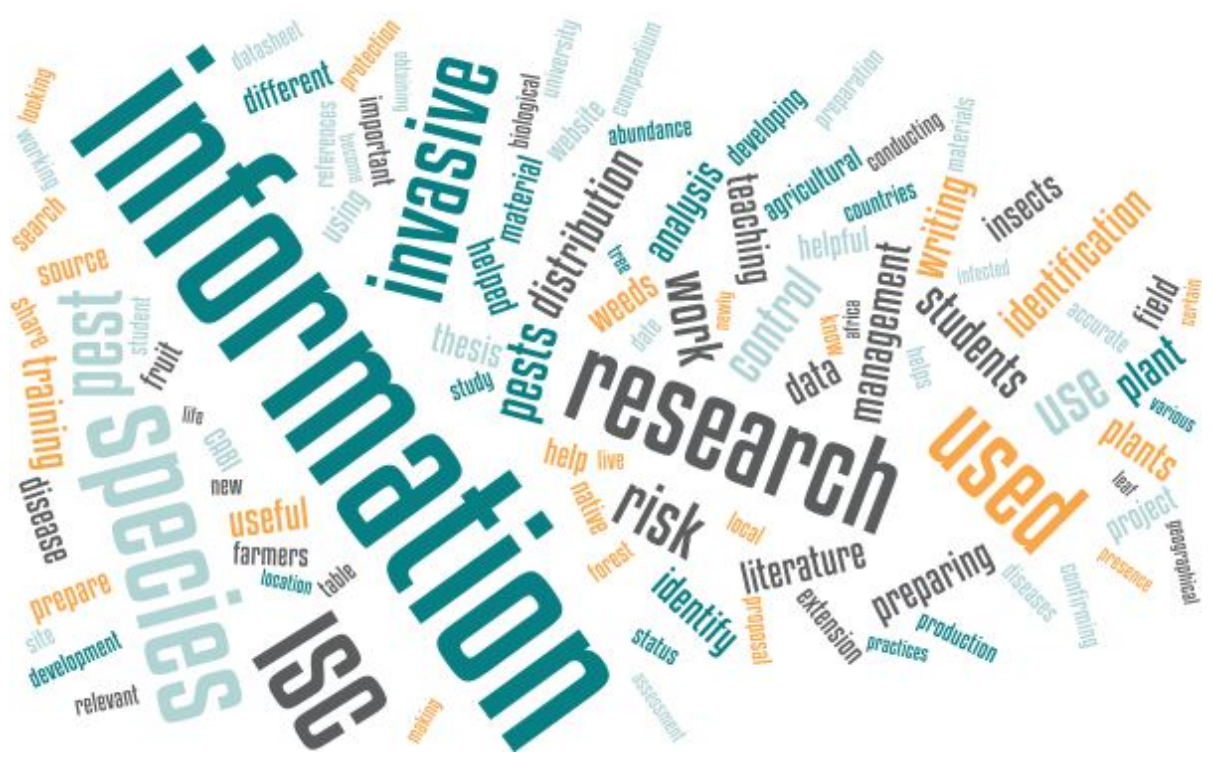

Fig. 7. Key words identified from Use question in 2020 SurveyMonkey and HotJar surveys. 


\section{Research}

In the HotJar survey of ISC users, $23.4 \%$ of respondents stated they used the ISC for research. These respondents included those undertaking professional research, academics and students. Professional and academic research topics included Chromolaena odorata (Siam weed) in North-western Tanzania, Bidens pilosa (blackjack), Bauhinia tomentosa (yellow bauhinia), Conopomorpha cramerella (cocoa pod borer), predators of Lepidiota stigma (sugarcane white grub), leaf disease vectors in Sri Lanka, and foot-and-mouth disease epidemiology. These respondents, from across the globe, stated that the information was valuable and very useful, and that they were surprised to find all the information in one place. They noted that the information was up to date, and that the ISC filled information gaps in the research they were undertaking.

Students at BSc, MSc and PhD levels used the ISC for academic purposes, in class assignments, course work, term papers, presentations, essays, research papers and their theses. Topics covered included FAW, P. absoluta, Bactrocera dorsalis (Oriental fruit fly) and other fruit flies, nematodes, and Acacia decurrens (green wattle). Other information used included the veterinary and aquaculture information and information related to rice pests and diseases. Respondents commented that the information is up to date, and they recommended the ISC to other students, due to the richness of the available information.

\section{Species identification}

Of the respondents to the HotJar survey $13.6 \%$ of ISC users stated they used the ISC for species identification, and noted that they had not found the necessary information elsewhere. It was used for identification of species collected from the field, plants, insect specimens, as well as to identify which plant species may become invasive in specific locations. Disease identification was possible due to the combination of images and the associated research information contained in the ISC. Specific identifications mentioned included Emex spp. and Sipha maydis.

\section{Teaching and training}

Of respondents in the HotJar survey of ISC users $11 \%$ used ISC information for teaching and training, especially at university level. Information was incorporated into teaching materials, training modules and lectures for both undergraduate and postgraduate students, with one respondent stating they had used ISC information in a project for secondary school students. Topics included economically important agricultural insect pests, plant pathology, honey bee diseases, fruit

Box 1. Teaching students in El Salvador.

Rafael Menjívar, a lecturer in the Crop Protection Department of the University of El Salvador, uses the ISC in his courses on integrated pest management. $\mathrm{He}$ introduces his students to the compendium, encouraging them to use it in their research as a source of scientific information. He states that it is very difficult to find written information about invasive species in El Salvador and the ISC provides excellent information to use both in class preparation and in his own research. Mr Menjívar is of the opinion that there is no other upto-date information about invasive species or quarantine pests for El Salvador, and therefore he always uses the ISC, especially as the information is accessible to everyone. diseases, and Cylindropuntia fulgida (jumping cholla). One respondent stated that they used the ISC to teach students about invasive insects that could become serious pests in El Salvador if they spread to that area (see Box 1). 
Other respondents also used the information to develop training material for farmers, as well as extension materials, stating that the ISC provided good reference material for farmer training and teaching integrated pest management (Box 2). Extension officers that operate under CABI's Plantwise programme stated that they use ISC information for advising farmers

Box 2. Supporting cabbage farmers in Jamaica. Lynroy Scott, an agronomist who works in the private sector in Jamaica, has used the ISC to provide information to farmers about the main cabbage pests and diseases in the country. The information was put together in a leaflet for farmers in a traditional cabbage-growing area, and included information on the locally available chemical and biological pest and disease control methods. They are currently monitoring uptake of the recommendations by farmers. Mr Scott chooses to use the ISC as he thinks the information is reliable, and he used CABI on invasive species management, such as FAW and P. absoluta. They use the information on the particular pests to compare with those found in the field, as well as information on crop rotation for $P$. absoluta, hand picking of FAW, control of fruit flies and Plutella xylostella (diamondback moth). The information also gets used to develop pest management decision guides, and factsheets for farmers on different pests (e.g. in Uganda).

\section{Risk assessment/analysis}

Pest risk assessment/ analysis (PRA) is a specialised field, but despite this $9.3 \%$ of respondents in the HotJar survey of ISC users used the ISC for risk analysis or assessment. Information was obtained about the presence of certain pests in specific geographic locations for use in PRA. In addition, the ISC was used when carrying out a PRA for fresh fruit, confirming the pest status in exporting countries, while another user carried out import risk analyses for new commodities. The ISC was used for the development of pest information packages to support market access for fruit and vegetable exports, and for risk assessments arising from requests to import live plants and seeds. Information was used to complete pest research and surveys, pest risk models, pest alerts, PRA reports and surveillance plans. Users included those who work in plant health quarantine, biosecurity and National Plant Protection Organisations.

\section{Preparation of information materials, databases and management plans}

While $5.7 \%$ of respondents in the HotJar survey of ISC users stated they had used the ISC for preparing extension materials, it appears that information was used in the development of many other types of information materials. Information, such as the distribution maps, data on biology, dispersal, and biological control, has been used to prepare field guides for surveillance in forest plantations, and a database of weeds local to Himachal Pradesh. A few users have translated the information (e.g. into Arabic to produce guidance leaflets, and into Spanish especially in relation to the common names of insects in Spanish). The information has been used in the development of management plans and pest survey programmes (e.g. for fruit fly where the programme included plans for early detection and risk management). The pest stage descriptions help in identifying the pest and discovering which management approaches best fit a management programme for that species. Other information materials include presentations on mango mealybug (no species name provided by respondent), information cards for gardeners and horticulturists to raise awareness of invasive species, and a bulletin of the major weeds in India, including their description, distribution, ecology and uses. Information has even been used in agrochemical trial reports and to develop a monograph of medicinal plants, where the origin of the plants was important to know. 


\section{General learning and usage}

The ISC has been used to learn more on invasive insect and plant species including their biology, distribution, known control methods, and natural enemies, as well as gaining general knowledge of the invasive species, damage and control. The information has been used in developing proposals for invasive species management. Other users visited the ISC to learn about the native distribution of species, whether a species is naturalised or invasive in a certain area, as well as the invasiveness of certain species, for example Neogobius fluviatilis (monkey goby), and its threat and invasion risk to a country. Users commented that the photos and images are extremely helpful for disease identification, and that the references act as a guide of where to seek further information when necessary.

\section{Benefits of the ISC}

Respondents in the HotJar survey of ISC users were also asked about the benefits of using the ISC, with the key response being that it provided quick access to relevant information $(17.6 \%)$ and that it provided accurate and up-to-date information (13.4\%). Respondents from lower income countries (Fig. 8) confirmed these findings, as well as stating that the ISC provides information in a useful format (12.5\%).

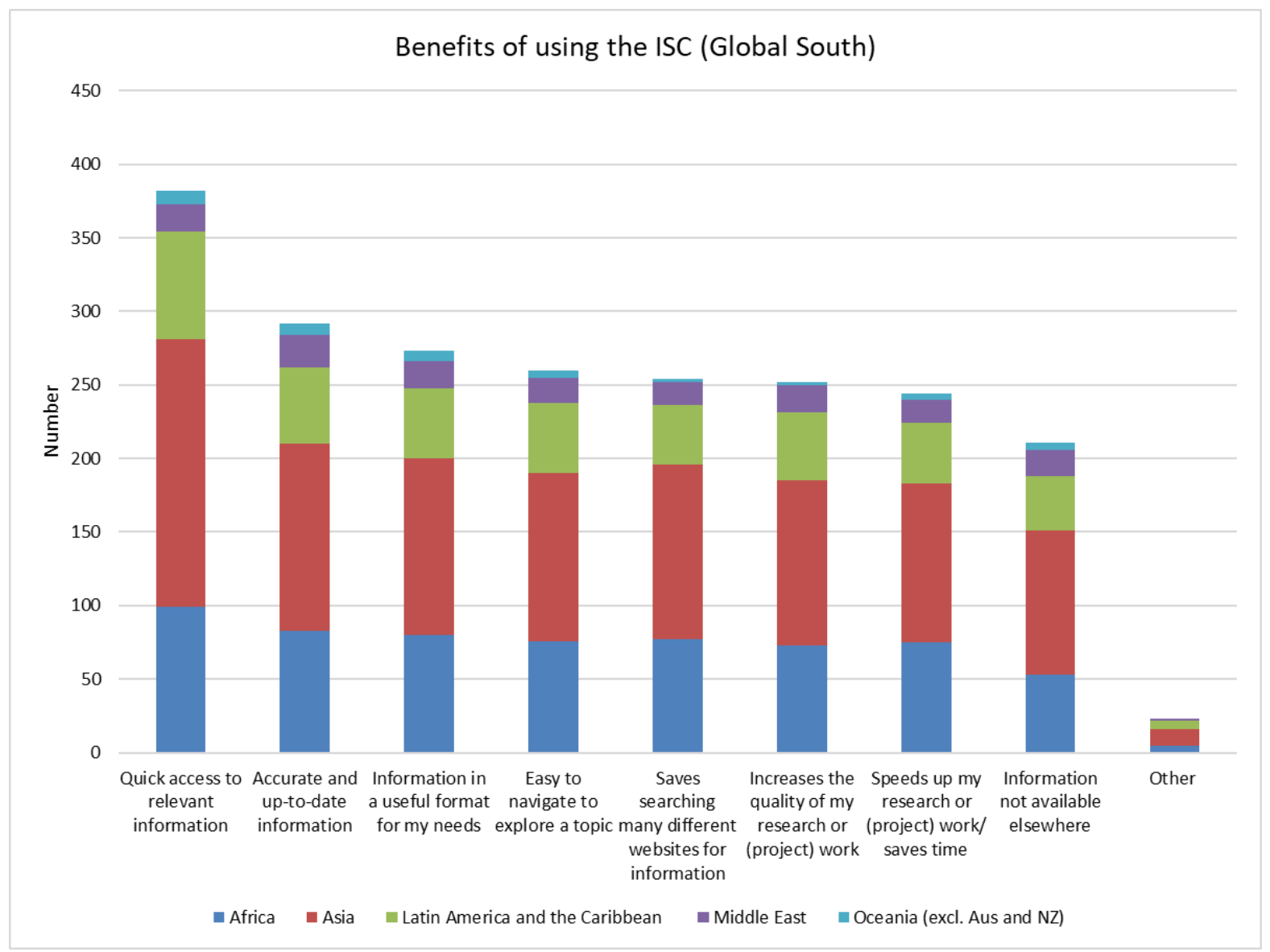

Fig. 8. Benefits of the ISC. Source: 2020 HotJar survey.

Users stated that the information was always helpful, very accurate and current, and that it provided a "good starting point for background information on pests". One respondent stated 
that the "ISC contains a lot of current and relevant information on invasive species" and that the collection and collation of relevant publications "makes it convenient for researchers and scientists to access information on one platform". Box 3 provides a specific example of the benefits of the use of the ISC.

Box 3. ISC use is second nature.

Dr Jan Hendrick Venter, who manages the Plant Health Early Warning section of the Department of Agriculture in South Africa, stated that use of the ISC is second nature to him. Whenever he requires pest information he enters the pest name and $\mathrm{CABI}$ as the search term and goes straight to the relevant ISC datasheet. Key uses of the data include pest risk analysis (which is where all the work in the Early Warning Section starts), development of training materials, development of phytosanitary regulations to control the spread of the pest, use of control information for eradication, and the biocontrol information for long-term control. He uses the ISC because the information is reliable and frequently updated.

A specific example of Dr Venter's use of the ISC is in their Exotic Fruit Fly survey programme, which is currently part of the Department of Agriculture's strategic plan. The work started in 2000 (though it was only officially launched in 2006) with the development of a trapping network for fruit fly. The programme was initially successful in eradicating the fruit fly outbreaks that occurred in the north of South Africa. During the first occurrence of the pest, a $30 \mathrm{~km}$ stretch was quarantined, and fruit fly was eradicated from that area. The country remained exotic fruit fly free for 55 weeks until the next outbreak, which was also eradicated. However, the period until the next occurrence was only 44 weeks this time. By 2013, it was no longer possible to eradicate exotic fruit fly from the northern and eastern parts of South Africa, though the southern and western areas of the country are still generally free from the pest. Eradication efforts in those areas still continue as it is considered more cost-effective than control and management efforts, which have to be undertaken by the commercial fruit companies. Initially use was made of the Crop Protection Compendium CDROMs. However, due to tight budget this subscription was not continued and through a chance internet search Dr Venter found the ISC. The ISC information has been used throughout the programme, and he finds the information on host range critical for surveillance activities, as well as the distribution maps. The information is also used to develop phytosanitary controls and regulations to govern the movement of host species and infested fruit within South Africa and across borders. The fact that the ISC is updated very regularly, especially with regards to host status, is another critical feature that enables Dr Venter to keep the phytosanitary regulations current and up to date.

So far, the programme has proved a great success, and CABI have played their role in that, due to the ISC, states Dr Venter. In theory it would be possible to obtain the required information elsewhere, through networks of species experts and literature searches, but accessing the ISC as the starting point for research saves a huge amount of time and effort. The ISC is now the starting point for any literature research on any invasive species, and the hyperlinked references make the work even easier, as he always verifies the data during his work. Dr Venter states that the ISC is really the only source of information on invasive species for developing countries. There are a few other sources, but they are not as comprehensive as the ISC and are not always open access. He estimated that the cost of accessing the information in the ISC from other sources, including verification of the ISC references would be approximately US $\$ 0.5$ million per annum. This sort of funding is just not available. To Dr Venter, access and accessibility are critical, with items such as ensuring that CABl's internet security certificates are current being essential to allow those working behind government firewalls to access the ISC.

\section{Examples of ISC use for individual species}

Given the wide variety of uses described, and the benefits that users state they gain from accessing the ISC, we now consider specific examples of use at the species level. Table 2 shows the most visited datasheets, with S. frugiperda and Litopenaeus vannamei (whiteleg 
shrimp or Pacific white shrimp) having over 75,000 page views between them globally. The visits for FAW is unsurprising as a main expected use of the ISC is that of providing information about new invasive species, especially as they spread to new areas. This is discussed further below.

L. vannamei (the second most commonly accessed datasheet in Asia) has been widely introduced around the world for aquaculture, and there have been many accidental escapes of the species into non-native areas. A key concern related to this species, is not the establishment of the species itself in new areas, but its ability to act as a vector of viral diseases that can affect native species as well as species used in aquaculture. This may be a factor in other species that have a high number of page views, as users seek to understand disease vectors, or alternatively what diseases affect specific crops (e.g. mango, bell pepper).

It is possible that the use of the ISC extends to broader management issues such as crop management, as the datasheets provide considerable information on the biology and ecology of species, which can be used for management. It is possible that the datasheets on rice, bitter gourd, coconut, guava and pearl millet are being used for crop management purposes, rather than seeking information about those species as invasives.

Use of the ISC as a source of biological and ecological information on species in general may also occur and explain why six out of the top ten sites visited in Oceania are all native to that area. This is somewhat supported by some of the user responses to the 2020 survey who stated that they used the ISC as a source of botanical information, to confirm common names, find pictures and the taxonomic tree for particular species and to identify plants and trees.

\section{Spodoptera frugiperda, fall armyworm (FAW)}

FAW has spread from the Americas to Africa and Asia recently, with the first sightings of FAW in West Africa in early 2016 (Goergen et al., 2016; Cock et al., 2017), spreading to most of the rest of Africa by 2017 (Abrahams et al., 2017; Day et al., 2017) and reported in countries across Asia from 2018 and in Australia in 2020 (FAO, 2020), as anticipated by Early et al. (2018).

Analysis of specific use of the ISC shows that the FAW datasheet has been visited the most over the last 3 years with over 57,000 page views (Fig. 9), with higher usage than the FAW species portal on the ISC. 


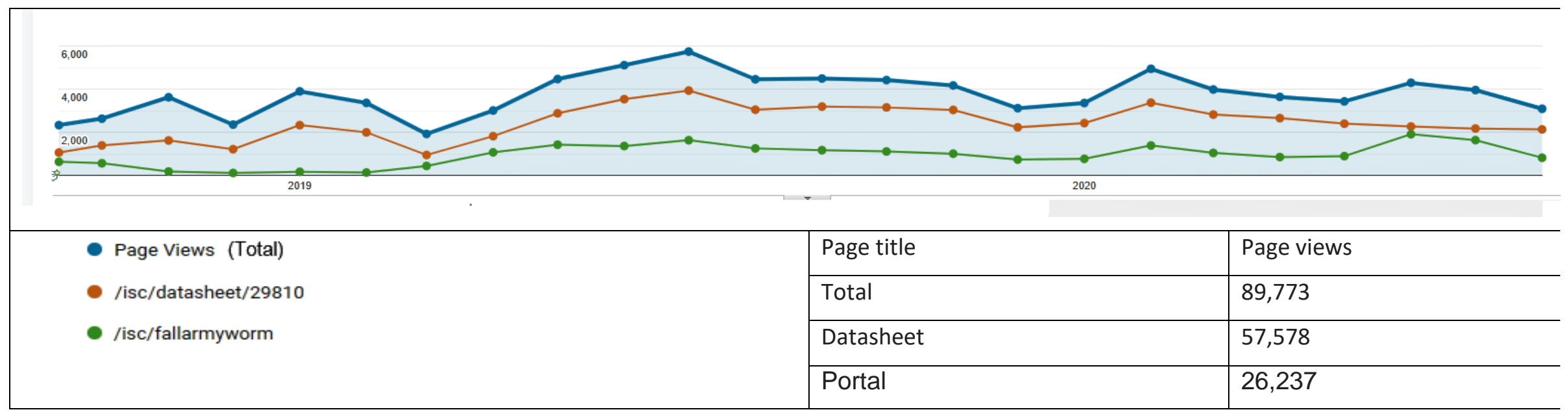

Fig. 9. Views of FAW information on the ISC (October 2018 to September 2020). Source: Google Analytics. 
Table 2. Top ten most visited datasheets (October 2018 to September 2020). Source: Google Analytics.

\begin{tabular}{|c|c|c|c|c|c|c|}
\hline & \multicolumn{2}{|l|}{ Asia } & \multicolumn{2}{|l|}{ Africa } & \multicolumn{2}{|l|}{ South America } \\
\hline & Species & $\begin{array}{l}\text { Page } \\
\text { views }\end{array}$ & Species & $\begin{array}{l}\text { Page } \\
\text { views }\end{array}$ & Species & $\begin{array}{l}\text { Page } \\
\text { views }\end{array}$ \\
\hline 1 & $\begin{array}{l}\text { Spodoptera frugiperda } \\
\text { (fall armyworm) }\end{array}$ & 32,389 & $\begin{array}{l}\text { Spodoptera frugiperda } \\
\text { (fall armyworm) }\end{array}$ & 7,570 & Oryza sativa (rice) & 2,311 \\
\hline 2 & $\begin{array}{l}\text { Litopenaeus vannamei } \\
\text { (whiteleg shrimp) }\end{array}$ & 13,555 & $\begin{array}{l}\text { Bidens pilosa } \\
\text { (blackjack) }\end{array}$ & 7,116 & Sorghum bicolor (sorghum) & 2,089 \\
\hline 3 & $\begin{array}{l}\text { Mangifera indica } \\
\text { (mango) }\end{array}$ & 12,586 & $\begin{array}{l}\text { Achatina fulica (giant } \\
\text { African land snail) }\end{array}$ & 4,290 & $\begin{array}{l}\text { Spodoptera frugiperda (fall } \\
\text { armyworm) }\end{array}$ & 1,645 \\
\hline 4 & $\begin{array}{l}\text { Momordica charantia } \\
\text { (bitter gourd) }\end{array}$ & 12,526 & Phthorimaea absoluta & 4,128 & Cocos nucifera (coconut) & 1,292 \\
\hline 5 & $\begin{array}{l}\text { Eleusine indica (goose } \\
\text { grass) }\end{array}$ & 10,113 & $\begin{array}{l}\text { Clarias gariepinus (a } \\
\text { fish) }\end{array}$ & 3,795 & $\begin{array}{l}\text { Fusarium oxysporum f. sp. } \\
\text { cubense (Panama disease of } \\
\text { banana) }\end{array}$ & 1,201 \\
\hline 6 & $\begin{array}{l}\text { Zingiber officinale } \\
\text { (ginger) }\end{array}$ & 9,387 & $\begin{array}{l}\text { cassava mosaic } \\
\text { disease }\end{array}$ & 3,775 & $\begin{array}{l}\text { Candidatus Liberibacter } \\
\text { solanacearum (zebra chip) }\end{array}$ & 868 \\
\hline 7 & $\begin{array}{l}\text { Pomacea canaliculata } \\
\text { (golden apple snail) }\end{array}$ & 9,205 & $\begin{array}{l}\text { Heterotis niloticus } \\
\text { (African bonytongue) }\end{array}$ & 3,765 & Poecilia reticulata (guppy) & 818 \\
\hline 8 & $\begin{array}{l}\text { Cocos nucifera } \\
\text { (coconut) }\end{array}$ & 8,862 & $\begin{array}{l}\text { Oreochromis niloticus } \\
\text { (Nile tilapia) }\end{array}$ & 3,734 & $\begin{array}{l}\text { Globodera rostochiensis (yellow } \\
\text { potato cyst nematode) }\end{array}$ & 727 \\
\hline 9 & $\begin{array}{l}\text { Psidium guajava } \\
\text { (guava) }\end{array}$ & 8,811 & $\begin{array}{l}\text { maize lethal necrosis } \\
\text { disease }\end{array}$ & 3,714 & $\begin{array}{l}\text { Leifsonia xyli subsp. xyli } \\
\text { (sugarcane ratoon stunting } \\
\text { disease) }\end{array}$ & 707 \\
\hline 10 & $\begin{array}{l}\text { Capsicum annuum } \\
\text { (bell pepper) }\end{array}$ & 8,529 & $\begin{array}{l}\text { Ageratum conyzoides } \\
\text { (billy goat weed) }\end{array}$ & 3,492 & $\begin{array}{l}\text { Pennisetum glaucum (pearl } \\
\text { millet) }\end{array}$ & 686 \\
\hline
\end{tabular}

\begin{tabular}{|c|c|c|c|c|c|c|}
\hline & \multicolumn{2}{|l|}{ North America } & \multicolumn{2}{|l|}{ Europe } & \multicolumn{2}{|l|}{ Oceania } \\
\hline & Species & $\begin{array}{l}\text { Page } \\
\text { views }\end{array}$ & Species & $\begin{array}{l}\text { Page } \\
\text { views }\end{array}$ & Species & $\begin{array}{l}\text { Page } \\
\text { views }\end{array}$ \\
\hline 1 & $\begin{array}{l}\text { Herpestes auropunctatus } \\
\text { (small Indian mongoose) }\end{array}$ & 15,029 & $\begin{array}{l}\text { Spodoptera frugiperda } \\
\text { (fall armyworm) }\end{array}$ & 6,278 & $\begin{array}{l}\text { Cherax destructor } \\
\text { (yabby) }\end{array}$ & 4,441 \\
\hline 2 & $\begin{array}{l}\text { Asterias amurensis (northern } \\
\text { Pacific seastar) }\end{array}$ & 12,526 & $\begin{array}{l}\text { Cydalima perspectalis } \\
\text { (box tree moth) }\end{array}$ & 5,723 & $\begin{array}{l}\text { Melaleuca } \\
\text { quinquenervia } \\
\text { (paperbark tree) }\end{array}$ & 3,856 \\
\hline 3 & $\begin{array}{l}\text { Mnemiopsis leidyi (sea } \\
\text { walnut) }\end{array}$ & 5,470 & $\begin{array}{l}\text { Drosophila suzukii } \\
\text { (spotted wing } \\
\text { drosophila) }\end{array}$ & 4,562 & $\begin{array}{l}\text { Cyathea cooperi } \\
\text { (Australian tree fern) }\end{array}$ & 3,684 \\
\hline 4 & $\begin{array}{l}\text { Cornu aspersum (common } \\
\text { garden snail) }\end{array}$ & 4,724 & Phthorimaea absoluta & 4,481 & $\begin{array}{l}\text { Spodoptera frugiperda } \\
\text { (fall armyworm) }\end{array}$ & 3,341 \\
\hline 5 & Helianthus annuus (sunflower) & 4,633 & $\begin{array}{l}\text { Erwinia amylovora } \\
\text { (fireblight) }\end{array}$ & 4,451 & $\begin{array}{l}\text { Pittosporum } \\
\text { undulatum (Australian } \\
\text { cheesewood) }\end{array}$ & 3,119 \\
\hline 6 & Artemia (brine shrimp) & 4,249 & $\begin{array}{l}\text { Vespa velutina (Asian } \\
\text { hornet) }\end{array}$ & 4,421 & $\begin{array}{l}\text { Asterias amurensis } \\
\text { (northern Pacific } \\
\text { seastar) }\end{array}$ & 2,988 \\
\hline 7 & $\begin{array}{l}\text { Pseudogymnoascus } \\
\text { destructans (white-nose } \\
\text { syndrome fungus) }\end{array}$ & 4,068 & $\begin{array}{l}\text { Halyomorpha halys } \\
\text { (brown marmorated } \\
\text { stink bug) }\end{array}$ & 4,310 & $\begin{array}{l}\text { Acacia melanoxylon } \\
\text { (Australian } \\
\text { blackwood) }\end{array}$ & 2,009 \\
\hline 8 & $\begin{array}{l}\text { Spodoptera frugiperda (fall } \\
\text { armyworm) }\end{array}$ & 4,037 & $\begin{array}{l}\text { Fallopia japonica } \\
\text { (Japanese knotweed) }\end{array}$ & 3,745 & $\begin{array}{l}\text { Rosmarinus officinalis } \\
\text { (rosemary) }\end{array}$ & 1,928 \\
\hline 9 & Sciurus niger (fox squirrel) & 3,795 & $\begin{array}{l}\text { Elodea canadensis } \\
\text { (Canadian pondweed) }\end{array}$ & 2,937 & $\begin{array}{l}\text { Bactrocera tryoni } \\
\text { (Queensland fruit fly) }\end{array}$ & 1,726 \\
\hline 10 & Myocastor coypus (coypu) & 3,734 & $\begin{array}{l}\text { Thaumetopoea } \\
\text { processionea (oak } \\
\text { processionary moth) }\end{array}$ & 2,866 & $\begin{array}{l}\text { Austropuccinia psidii } \\
\text { (myrtle rust) }\end{array}$ & 1,706 \\
\hline
\end{tabular}


Further analysis of the usage of the FAW pages in the ISC has shown that the usage correlates with when the pest has been reported in a country or region. For example, FAW was first reported in Asia in July 2018, and visits to the datasheet increased immediately (Fig. 10). When analysed by country it possible to see more variation in visits to the datasheet as well as the FAW portal, which was launched in September 2018. The graphs indicate that the portal was immediately accessed and used across Asia. For example, visits in Bangladesh, Nepal, Thailand, Myanmar and China started to increase before FAW was reported in these countries, either through the media or the International Plant Protection Convention (IPPC)/ Food and Agriculture Organization of the United Nations (FAO). However, in India, visits only started to increase after the pest had been reported (Fig. 11). As FAW reached India in May 2018 (Sharanabasappa et al., 2018), earlier than other countries in the region (late 2018 to early 2019), it is possible that India was not aware of the probability of spread of FAW before its invasion. Therefore, visits to the ISC for FAW information only increased in response to the presence of the pest in the country, and researchers and others sought information on how to manage the pest. However, the presence of the pest in India would have increased awareness of FAW in nearby countries, leading to increased visits to the FAW pages as researchers sought to learn about the pest before it was found in countries such as China, Bangladesh and Myanmar. In both cases, it appears that the ISC was a useful resource that researchers turned to, to learn about FAW as a new invasive pest in Asia.

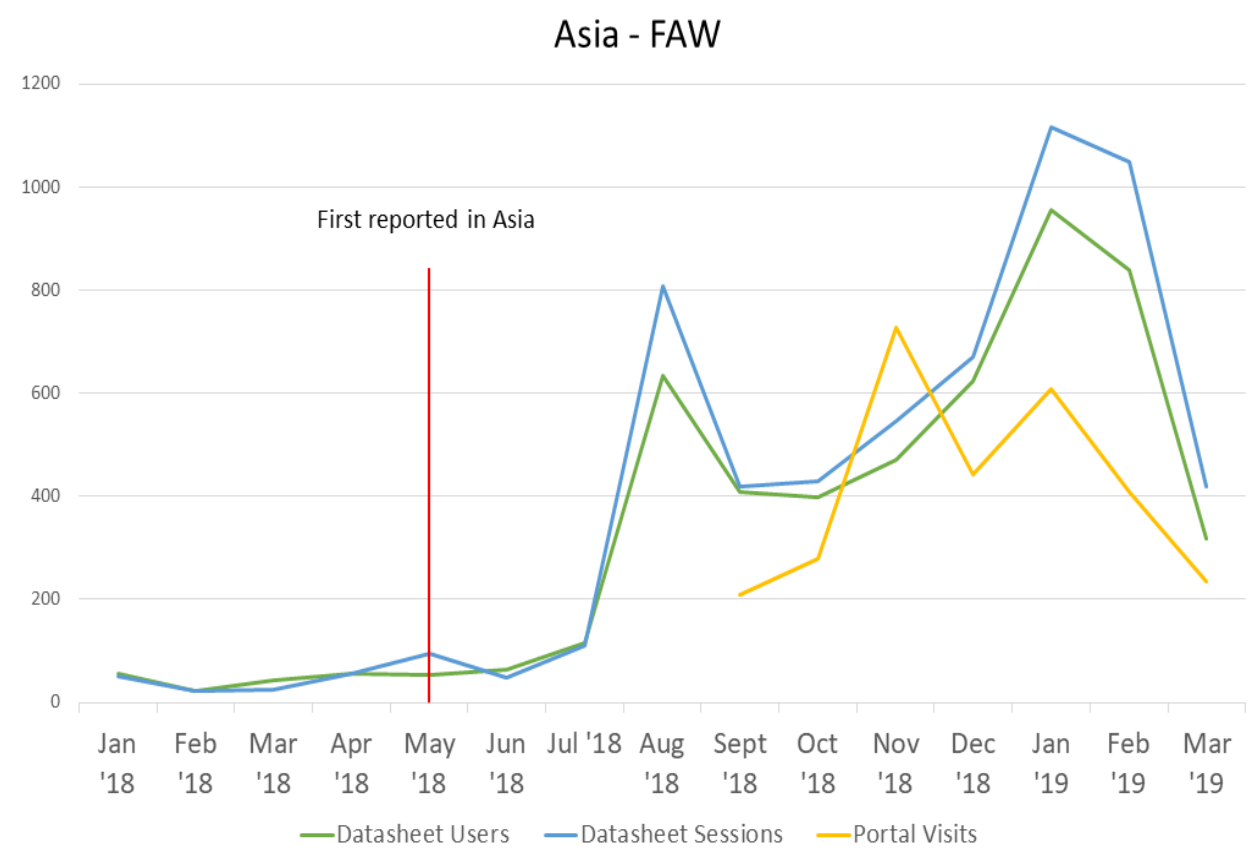

Fig. 10. ISC users from Asia viewing the FAW datasheet and portal. Source: FAW data usage analysis. 
Bangladesh - FAW
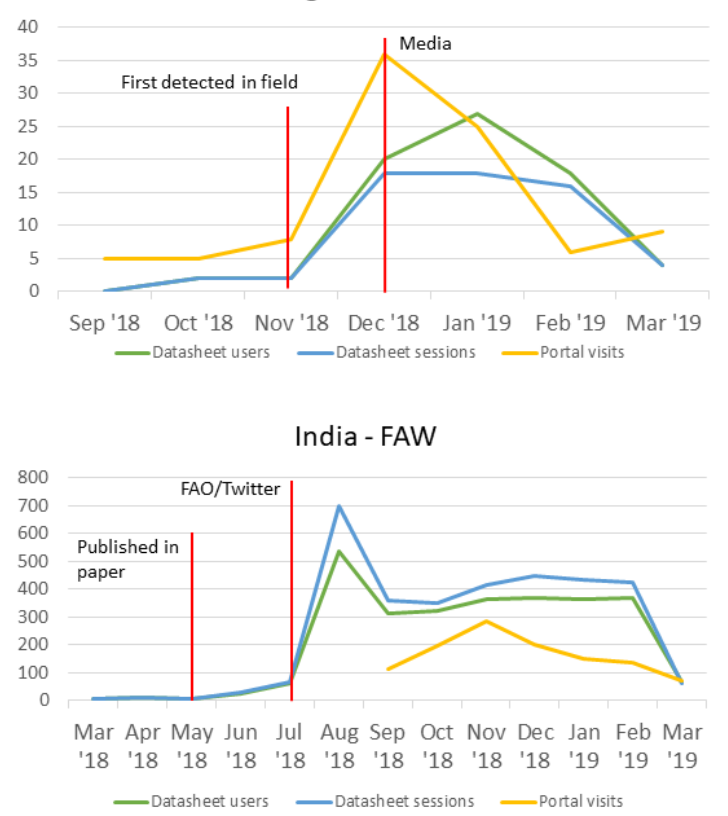

China - FAW

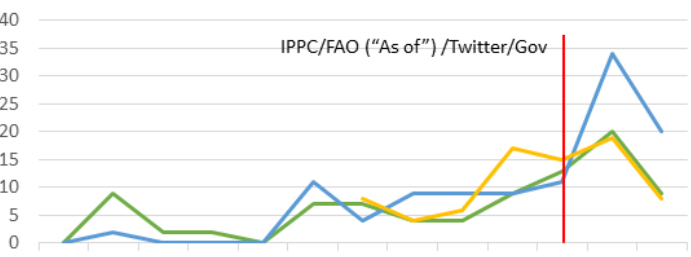

Mar Apr May Jun Jul Aug Sep Oct Nov Dec Jan Feb Mar '18 '18 '18 '18 '18 '18 '18 '18 '18 '18 '18 '19 '19

—Datasheet users —Datasheet sessions —Portal visits

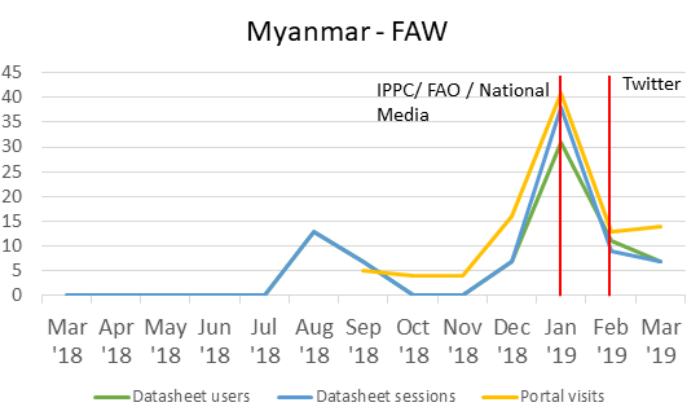

Fig. 11. ISC users from Bangladesh, China, India and Myanmar viewing the FAW datasheet and portal. Source: FAW data usage analysis. Red lines indicate when FAW was first mentioned by the organisation or through the media specified.

Respondents to the 2020 SurveyMonkey and HotJar surveys stated that the FAW pages are "the best example of using your website" and that "it provides a full set of information, updated maps and distribution worldwide". Uses include preparing training courses and training FAW scouts with information on host expectations, life cycles, abundance, etc. In particular a scientist from the International Centre of Insect Physiology and Ecology (icipe) stated that the ISC contains a lot of current and relevant information on invasive species, especially the FAW. Publications produced by the CABI team on the impact of the FAW on yield, incomes, threats to food security and spread, such as the Fall armyworm: impacts and implications for Africa (Abrahams et al., 2017) and the Fall armyworm: impacts and implications for Africa. Evidence Note Update (Rwomushana et al., 2018), which are accessible from the ISC, are rich resources that provide valuable information for research, proposals development and publications, thus anyone writing on invasive species has to refer to the ISC resources. In addition, efforts by CABI to collect and collate other relevant publications on invasive species, especially publications and datasheets, on one platform makes it convenient for researchers and scientists to access information on one platform. The team at icipe uses the manual, posters and brochures developed by $\mathrm{CABI}$, and shared on the ISC, on the management of the FAW to train farmers in Africa. Furthermore, the user says information on the ISC is credible because it is backed by scientific research. 


\section{Cuscuta spp., field dodder}

Field dodder (Cuscuta) is a genus of parasitic weeds some of which have been introduced into countries beyond their native range in North America. They have a wide host range, and when introduced to a new area are likely to find suitable host plants. It has a wide vegetative spread and tolerance to different climatic conditions (CABI, 2020b). It contaminates crop seeds as dodder seed is hard to separate and therefore is easily spread. Recently dodder (Cuscuta campestris, Cuscuta kilimanjari and Cuscuta reflexa - see Masanga et al., 2020) has been spreading across Kenya and invading new areas including tea farms (Otieno, 2016). Due to this spread, it is a species that the Kenya Plant Health Inspectorate Service (KEPHIS) is monitoring through field pest surveillance. During this process, KEPHIS staff have used ISC information to support their work. For example, when carrying out surveillance activities in several counties in Kenya, the KEPHIS team observed a huge number of infestations of dodder. Members of the surveillance team visited the ISC to learn about the species, including its biology and ability to act as a parasitic weed that feeds on the host. This information enabled the team to provide appropriate management advice to farmers immediately, which was particularly needed as farmers did not seem to know about the destructive nature of Cuscuta spp., especially when attacking fruit trees and coffee.

"Information from the Invasive Species Compendium (ISC) and Crop Protection Compendium (CPC) has been resourceful in our surveillance of pests and invasive weeds. During some of the surveillances in Nakuru, Kakamega, Uasin Gishu, Murang'a and Kiambu, we noticed a lot of the Cuscuta weed on farm hedges, trees and even on coffee. The information I accessed from ISC and CPC on identification, biology and management of Cuscuta species was helpful in advising farmers on the appropriate management of Cuscuta. After informing farmers on the parasitic nature of Cuscuta where it was found, we advised the farmers to immediately uproot the weed and burn it when they see it, because it is a destructive parasitic weed that spreads fast, and that they should avoid spreading it further by planting it as an ornamental plant." Kevin Sambai, KEPHIS.

\section{Schistocerca gregaria, desert locust}

Recently the ISC has been used to obtain information during the S. gregaria outbreak that is being experienced in East Africa and parts of Asia (Fig. 12), with an obvious increase in use when the outbreak started in early 2020. The datasheet contains information, including pictures of the different growth stages of the locust as well as its natural enemies.

In Kenya, a member of the Desert Locust Control Coordination Committee stated that they use the ISC substantially. Members of the Committee used information from the ISC to develop a factsheet on managing desert locusts, and in March 2020, a team from the University of Nairobi, including the committee member, organised a symposium to discuss the desert locust situation in Kenya, including possible management strategies. The committee member stated that the ISC played a substantial role in providing the necessary information on S. gregaria. ISC information is also being used by the committee member and others to develop a proposal on managing the desert locust in Kenya, as well as to write a review paper on S. gregaria. In addition, the respondent stated that he always recommends the ISC to his students as the ISC and CPC are rich knowledge bases on invasive species, and he conducts demonstrations in class of these resources. 


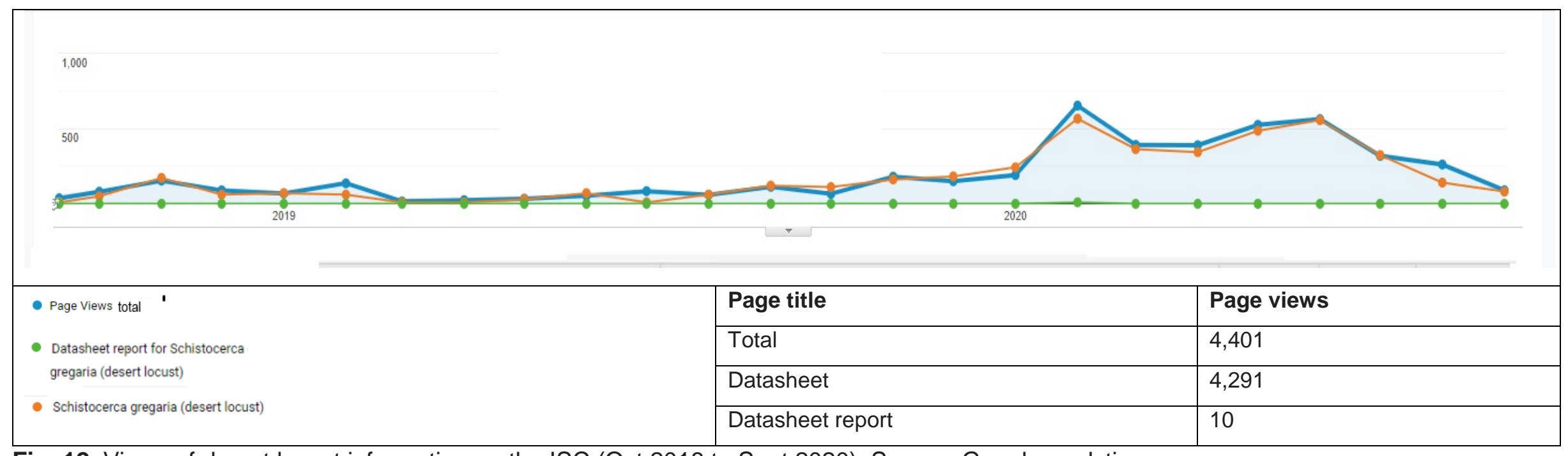

Fig. 12. Views of desert locust information on the ISC (Oct 2018 to Sept 2020). Source: Google analytics 


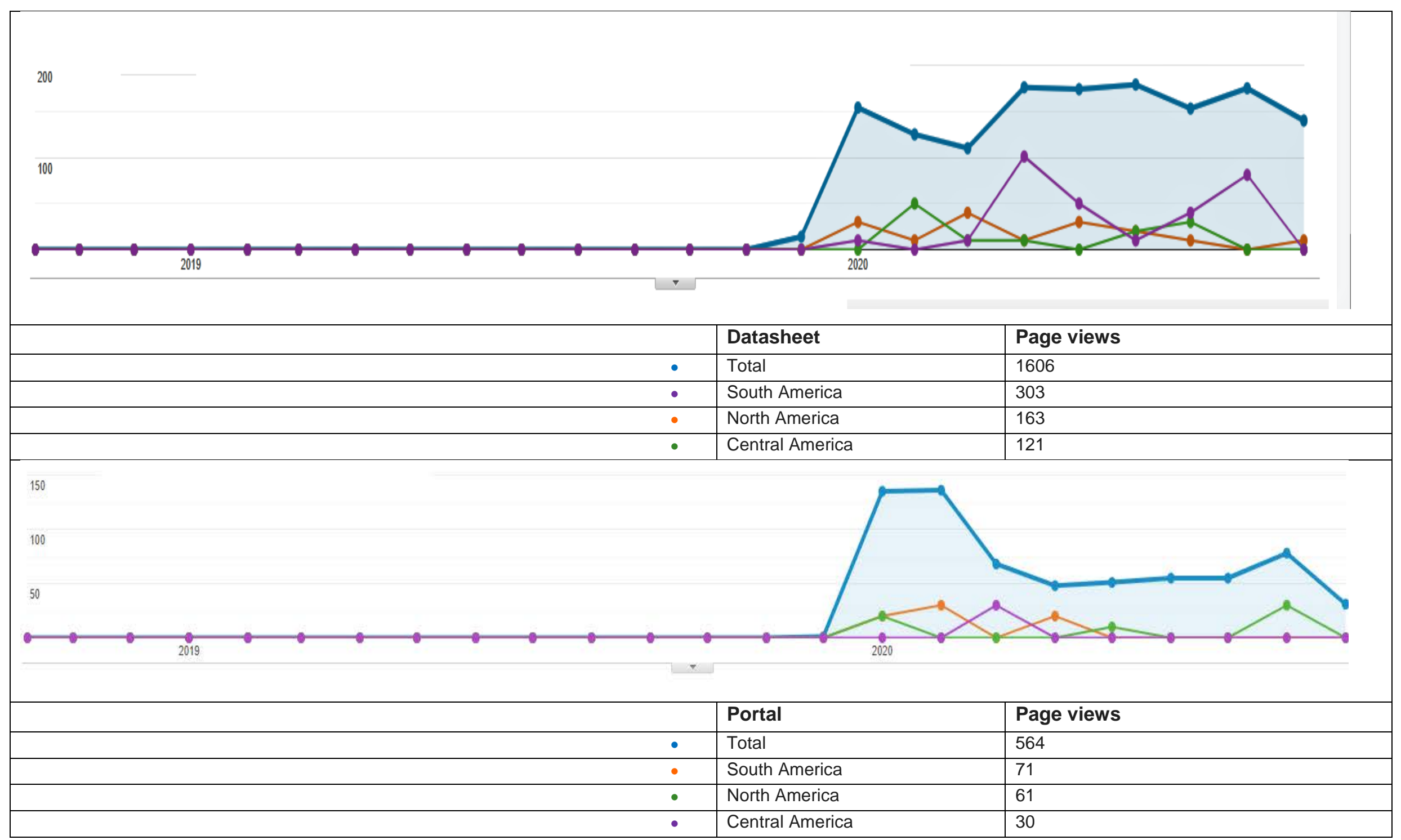

Fig. 13. Views of Fusarium oxysporum f. sp. cubense tropical race 4. Source: Google Analytics. Information on the ISC, datasheet and TR4 ISC species portal (October 2018 to October 2020). The TR4 portal was launched in December 2019. 


\section{Fusarium oxysporum f. sp. cubense tropical race (TR4)}

A further example of how the ISC is used in response to new pest and disease outbreaks is that of the soil-borne fungus, Fusarium oxysporum f. sp. cubense tropical race (TR4), which is severely affecting global banana production. It infects most banana cultivars but especially the Cavendish variety that forms almost all of the global trade in bananas (CABI, 2020c). It has devasted commercial Cavendish plantations in Asia and Oceania (CARICOM and CAHFSA, 2020). It was found in Colombia in 2019, and six farms were quarantined, and 175 ha of banana plantation were destroyed (ProMusa, 2019). The datasheet and the references within the datasheet were used to develop the CARICOM/CAHFSA factsheet, and Fig. 13 demonstrates the increase in use of the ISC resources in January 2020, which seemed to have been in response to the outbreak in South America.

\section{General observations and suggested improvements}

In both 2020 surveys, respondents made some general observations about the ISC, with suggestions for improvements. In general, there appeared to be some confusion between the CPC and the ISC, especially due to the overlap of data within the two compendia. In addition, there was a low level of awareness of the ISC, as evidenced in the first 2020 survey where members of the Kenya FAW taskforce and the Entomological Society of Kenya had very little awareness of the ISC. Specific feedback falls into a number of categories below, with a development suggestion included in Box 4.

\section{Updating the ISC}

A considerable number of respondents stated that a key improvement is to ensure that the information is regularly updated, especially with regards to new research, cited literature, country species distributions, supporting tables, etc. It was suggested that it would be useful for the ISC to state: (i) the date when the information was last updated; (ii) that all the information on pest distribution is based on primary sources; and (iii) the links to distribution data sources. This would help users to assess the accuracy of the information. It is worth noting that the datasheets already have a 'last modified' field providing the date of last update, so it is worth considering whether other date fields are needed or whether the terminology of the current field needs further clarification.

Box 4. Feedback, alerts and use of distribution maps.

Dr Venter provided feedback on features that he would find useful to see within the ISC. This included creating a feedback loop that gave users a clear way to provide information to the ISC that would assist in identifying new species for which the ISC should provide information and resources.

An additional feature that would be useful would be an alert feature based on species spread. For example, if a species was known to be spreading across a continent and had reached country $x$, then an alert could be included on the ISC to warn the neighbouring country to prepare for that invasive species. This may need to be based on distribution maps and modelling of the spread of the species.

A final suggestion was making use of the distribution maps over time to produce an animation that shows how invasive species spread from one country to the next and the speed at which this can happen. Dr Venter stated that this would be a very useful resource for teaching about invasive species. 


\section{Images}

A large number of respondents commented on the use of images in the ISC, with requests to increase the quantity, and sometimes the quality of the images included. Specific suggestions included requests to include an insect picture gallery, more detailed photos of pests and pest damage on host species, as well as include more images from the field rather than the laboratory, and images that were free for other organisations to use. One respondent commented that "pictures depict a thousand words".

\section{Distribution information}

A number of comments were received about the distribution information in the ISC. Requests included information on: (i) the native range of invasive species versus the introduced distribution especially in the maps; (ii) the mode of introduction of the invasive to different regions; and (iii) information on whether a pathogen is a quarantine disease/pest in different countries.

\section{Tools}

There were some comments from users about the PRA Tool, a specialist tool (www.cabi.org/PRA-Tool) which is driven by the more extensive crop and pest data in the CPC. It is currently provided as an additional subscription to the CPC, and a gratis subscription is offered to National Plant Protection Organisations in lower income countries. Some respondents requested that it is made free for all users. A PRA instruction manual was requested and also more information about risk assessments for specific species and methods to evaluate new pests. Other users requested further support in identification of pest species through their development stages (for insects), and their natural enemies. A final group of users requested the ability to download the datasheets and factsheets as pdf documents and to request new datasheets.

\section{References and citations}

The comments received on references mainly referred to accessibility of the referenced information, and may correspond to the confusion between the ISC and the CPC. One user commented that the datasheet was not available to non-members, though the ISC is open access. It is possible that the user may have accessed the datasheet through the CPC instead. Other users requested that the referenced material, including publications, was made accessible to all rather than just those who had subscriptions to journals and CABI abstracts through institutional log ins. A few users commented that it would be helpful to have citations for host listings, as well as have an easy way to cite the datasheets, and different citation formats available.

\section{Structure and navigation}

Users requested additional classification and categorisation of the information in the ISC, and commented that the display could be improved, for example subheadings should have "popping view" to make it easier to find information in the different sections. This comment is somewhat unclear but may mean that the information under each subheading should be hidden until the user clicks on that subheading.

\section{Search function}

Some users commented that the search function was difficult to use, and that they cannot find the datasheets that they are interested in, so usually search in Google and access the ISC 
that way. A specific suggested improvement was that when a search term was misspelt (e.g. a species name), the search should return nearest results (species information closest to the name) rather than state that there was no information available. It was also felt that there could be increased search engine optimisation within Ecosia2 (Bing driven), a better search engine from CABI's homepage and a direct link from the homepage to take users to the ISC.

\section{Mobile enabled}

A small number of respondents commented that it would be useful if the ISC were mobile enabled, and that having the ISC as an app would be useful when carrying out fieldwork.

\section{Publicity}

Following on from the observation that there is limited awareness about the ISC, a few respondents commented that greater publicity or advertising would be useful, as they had only come across the site by accident. One specific suggestion was that advertising is allowed on the site, with the revenue being used to publicise the site.

\section{Guide to new users}

A final suggestion from users is that because there is so much information in the ISC, it can be overwhelming, hence it may be helpful to develop an introductory video tutorial, or a guide to make it easy for newcomers to get the information they need quickly.

\section{Conclusions}

Different forms of ICTs are now a very common method to deliver and share technical information with e-resources rapidly developing to become the first source of information instead of information found in paper forms. A key advantage of e-resources is that they can disseminate up-to-date information and knowledge (Parthasarathy, 2014). The findings presented here demonstrate that there are three key features of the ISC that are of particular value to users: (i) the information is reliable; (ii) the information is up to date; and (iii) the ISC is open access. The fact that the information is reliable and up to date means that users trust the compendium and are confident using the information. It also means that they do not necessarily check other web resources for information, though they will access the references that are included on the datasheets. These two features mean that there is a considerable time saving for researchers, which aligns with the findings of Guruprasad (2017) and Bhat (2019), and therefore cost savings in terms of reduced time needed for the initial research (Pearce and Monck, 2006). The third key feature, that the ISC is open access, is of critical importance to those users from the Global South, where budgets for invasive species research are particularly limited. It is apparent from the findings here, that if the ISC was not open access, many researchers in the Global South would not have the means to pay for access to this information, or would have to choose between spending funds on accessing information, or on carrying out field surveys and other primary research. The open access nature of the ISC brings real benefits to these researchers in terms of money saved. These key features lead to the view from users, primarily researchers, that the ISC is the starting point of any work on invasive species.

A review of other web resources that focus on invasive species suggests that the few that have global coverage (i.e. GISD, INVASIVESNET, GISIN) are not necessarily up to date (e.g.

2 https://www.ecosia.org/ 
GISD), or do not have as comprehensive global coverage (e.g. GISIN), unlike the ISC. These findings correspond to those of Coughlan et al. (2020) who rated the ISC the best of four invasive species databases when comparing species, impact and control information and source materials. The more localised websites that provide up-to-date country invasives information focus on countries where research funding resources are not so limited (e.g. Australia), whereas funding and resources to keep the global websites up to date is challenging (Jarnivick et al., 2015). The few web resources that focus on providing invasive species information for Global South countries appear to make use of the ISC information as a primary resource, again providing evidence of the reliability of the information in terms of its relevance and accuracy.

This value to Global South researchers is demonstrated by the use of the compendium in response to new pest and disease outbreaks, such as FAW, desert locust or TR4. The evidence demonstrates that use of the ISC datasheets and portals increase considerably as a new species enters a country or region, not just from the affected country, but also from surrounding countries, as researchers there seek to learn about the invasive species before they experience an outbreak. It is unclear from the review of other open access invasive sources whether the same information would be available to these researchers elsewhere, or whether it would be as reliable.

A further point that this study has highlighted is that it appears that many users of the ISC are not necessarily just searching for information on invasive species. It appears from the survey feedback and the analytics data that for some listed species, including $L$. vannamei and Mangifera indica (mango) as two of the most viewed datasheets, users may be accessing the ISC for information on the biology and management of species. This may include information on pests that affect the crop species, climatic suitability or even basic data such as species identification and confirmation of common names, regardless of whether the species are invasive in the area in which the user lives or works.

Finally, in terms of future development of the ISC, it is worth noting two key points that were apparent from both the survey feedback and the key informant interviews. First, it appears that a considerable number of users were not aware of the ISC and came across it by accident, especially through the use of search engines. This demonstrates the critical nature of the search engine optimisation work that was carried out in 2019 , but also highlights the potential need for additional marketing or awareness raising of what is considered a valuable resource by those who do use it. Secondly, even for users who were familiar with the resource, they did not use the search function on the ISC homepage. Instead they used a generic search engine and search term of 'species name' and 'CABl'. This suggests, as supported by the survey feedback, that the search function within the ISC could be improved.

Overall, this study has shown that the ISC is highly valued by users, and that in many cases, especially in the Global South, research would be considerably affected if the ISC was no longer updated or did not remain as an open access resource. In terms of comprehensive information on invasive species for the Global South, it appears that no other website provides the same level of comprehensive and up-to-date information and is an essential element of invasive species research. 


\section{References}

Abrahams, P., Bateman, M., Beale, T., Clottey, V., Cock, M., et al. (2017) Fall armyworm: impacts and implications for Africa. Evidence Note (2), September 2017. Available at: https://www.cabi.org/isc/FullTextPDF/2018/20187200428.pdf (accessed 24 Sept 2020).

Ademola, F.O., Obukowho, R.E. and Emuejevoke, P.O. (2015) Usage of electronic information resources (EIRs) by undergraduate students of Federal University of Petroleum Resources Effurun. Information and Knowledge Management 5(4), 94-104.

Ani, O.E., Ngulube, P. and Onyancha, B. (2015) Perceived effect of accessibility and utilization of electronic resources on productivity of academic staff in selected Nigerian universities. SAGE Open 1-7. DOI: 10.1177/2158244015607582

ASEAN Centre for Biodiversity (2020) Invasive Alien Species. Available at: http://chm.aseanbiodiversity.org/invasivealienspecies/ (accessed 22 Sept 2020).

Bhat, N.A. (2019) Impact of electronic information resources on the mindset of researchers. International Journal of Digital Literacy and Digital Competence 10(1). DOI: 10.4018/IJDLDC.2019010103

Bhat, N.A. and Ganai, S.A. (2017) Impact of availability of e-resources on user satisfaction in agricultural libraries of Northern India. SRELS Journal of Information Management 54(1), 5154. DOI: $10.17821 / \mathrm{srels} / 2017 / \mathrm{v} 54 \mathrm{i} 1 / 109488$

CABI (2020a) About the Invasive Species Compendium. CAB International, Wallingford, UK. Available at: https://www.cabi.org/isc/about (accessed 20 Sept 2020).

CABI (2020b) Cuscuta campestris. In: Invasive Species Compendium. CAB International, Wallingford, UK. Available at: https://www.cabi.org/isc/datasheet/17111 (accessed 10 Jan 2021).

CABI (2020c) Fusarium oxysporum f. sp. cubense tropical race 4. In: Invasive Species Compendium. CAB International, Wallingford, UK. Available at: https://www.cabi.org/isc/datasheet/59074053 (accessed 24 Sept 2020)

CARICOM and CAHFSA (2020) Fusarium Wilt Tropical Race 4 (TR4). Caribbean Community and Common Market (CARICOM) and Caribbean Agricultural Health and Food Safety Agency (CAHFSA). Available at: https://agriculture.gov.tt/wp-content/uploads/2020/07/TR4Fusarium-Wilt.pdf (accessed 24 Sept 2020)

Cock, M.J.W., Beseh, P.K., Buddie, A.G., Cafá, G. and Crozier, J. (2017) Molecular methods to detect Spodoptera frugiperda in Ghana, and implications for monitoring the spread of invasive species in developing countries. Scientific Reports 7(1), 4103.

Coughlan, N.E., Lyne, L., Cuthbert, R.N., Cunningham, E.M., Lucy, F.E., et al. (2020) In the black: information harmonisation and educational potential amongst international databases for invasive alien species designated as of Union Concern. Global Ecology and Conservation 24: e01332. DOI: 10.1016/j.gecco.2020.e01332

Day, R., Abrahams, P., Bateman, M., Beale, T., Clottey, V., et al. (2017) Fall armyworm: impacts and implications for Africa. Outlooks on Pest Management 28(5), 196-201. DOI: 10.1564/v28_oct_02

Dhanavandan, S. and Tamizhchelvan, M. (2012) An evaluation of e-resources in academic libraries in Tamil Nadu. Journal of Emerging Trends in Computing and Information Sciences 3(3), 421-426.

Early, R., González-Moreno, P., Murphy, S.T. and Day R. (2018) Forecasting the global extent of invasion of the cereal pest Spodoptera frugiperda, the fall armyworm. NeoBiota 40, 25-50. 
FAO (2020) Fall armyworm. Food and Agriculture Organization of the United Nations, Rome. Available at: http://www.fao.org/fall-armyworm/monitoring-tools/faw-map/en/ (accessed 24 Sept 2020).

Goergen, G., Kumar, P.L., Sankung, S.B., Togola, A. and Tamò, M. (2016) First report of outbreaks of the fall armyworm Spodoptera frugiperda (JE Smith) (Lepidoptera, Noctuidae), a new alien invasive pest in West and Central Africa. PLOS ONE 11(10): e0165632.

Guruprasad, R. (2017) Impact and significance of electronic information resources among aerospace scientists, engineers and technologists of Bangalore: a research survey. International Journal of Innovative Research in Science, Engineering and Technology 6(1), 246-262.

International Association for Open Knowledge on Invasive Alien Species (2020) INVASIVESNET. Available at: https://invasivesnet.org/ (accessed 22 Sept 2020).

Invasive Species Council (2020) Available at: https://invasives.org.au/resources/ (accessed 22 Sept 2020)

IUCN ISSG (2020a) Global Invasive Species Database. International Union for Conservation of Nature (IUCN) Invasive Species Specialist Group (ISSG), Gland, Switzerland. Available at: http://issg.org/database/reference/index.asp (accessed 22 Sept 2020).

IUCN ISSG (2020b) Global Register of Introduced and Invasive Species. International Union for Conservation of Nature (IUCN) Invasive Species Specialist Group (ISSG), Gland, Switzerland. Available at: http://www.griis.org/about.php (accessed 22 Sept 2020)

Jarnivick, C.S., Simpson, A., Graham, J.J., Newman, G.J. and Bargeron, C.T. (2015) Running a network on a shoestring: the Global Invasive Species Information Network. Management of Biological Invasions 6(2), 137-146.

Lucky, U.H. and Chowdhury, S. (2012) Use of electronic resources and its impact: a study of Dhaka University Library users. The Eastern Librarian 23(1), 74-90.

Lucy, F.E., Roy, H., Simpson, A., Carlton, J.T., Hanson, J.M., et al. (2016) INVASIVESNET towards an International Association for Open Knowledge on Invasive Alien Species. Management of Biological Invasions 7(2), 131-139. DOI: 10.3391/mbi.2016.7.2.01

Manda, P. and Nawe, J. (2008) The impact of electronic information resource use on research output: experiences from Universities in Tanzania. University of Dar es Salaam Library Journal 10(1-2). DOI: 10.4314/udslj.v10i1-2.43418

Masanga, J. Mwangi, B.N., Kibet, W., Sagero, P., Wamalwa, M., et al. (2020) Physiological and ecological warning that dodder pose an exigent threat to farmlands in Eastern Africa. bioRxiv preprint DOI: https://doi.org/10.1101/2020.10.26.355883

Onyango, D., Muitherero, N.F., Day, R. and Parr, M. (2016) E-resources for agricultural research capacity building in African universities. CABI Study Brief 17. CAB International, Wallingford, UK. DOI: 10.1079/CABICOMM-45-118

Otieno, J. (2016) Who will stop this parasitic weed's fast spread? In: The Standard. Available at: https://www.standardmedia.co.ke/wednesday-life/article/2000200572/who-will-stop-thisparasitic-weeds-fast-spread (accessed 10 Jan 2020)

Pagad, S., Genovesi, P., Carnevali, L., Scalera, R. and Clout, M. (2015) IUCN SSC Invasive Species Specialist Group: Invasive alien species information management supporting practitioners, policy makers and decision takers. Management of Biological Invasions 6(2), 127-135. DOI: 10.3391/mbi.2015.6.2.03

Parthasarathy, R. (2014) Impact of electronic resources on academic program in arts and science colleges Tiruchirappalli: a study. PhD Thesis, Annamalai University, Chidambaram, India. Available at: http://hdl. handle.net/10603/186505 (accessed 21 Sept 2020). 
Pearce, D. and Monck, M. (2006) Benefits to Australia of Selected CABI Products. Impact Assessment Series Report No. 42. Australian Centre for International Agricultural Research, Canberra.

ProMusa (2019) TR4 in Colombia. Available at: https://www.promusa.org/blogpost620-TR4in-Colombia (accessed 22 Sept 2020).

Rwomushana, I., Bateman, M., Beale, T., Beseh, P., Cameron, K., et al. (2018) Fall armyworm: impacts and implications for Africa. Evidence Note Update, October 2018. 52 pp. Available at: https://www.invasive-species.org/wp-content/uploads/sites/2/2019/02/FAWEvidence-Note-October-2018.pdf (accessed 20 Sept 2020).

Sharanabasappa, D., Kalleshwaraswamy, C.M., Asokan, R., Mahadeva Swamv, H.M., Maruthi, M.S., et al. (2018) First report of the fall armyworm, Spodoptera frugiperda (J.E. Smith) (Lepidoptera: Noctuidae), an alien invasive pest on maize in India. Pest Management in Horticultural Ecosystems 24(1), 23-29.

Tenopir, C. (2012) Beyond usage: measuring library outcomes and value. Library Management 33(1/2), 5-13. DOI: 10.1108/01435121211203275

USDA (2020) National Invasive Species Information Center (NISIC). United States Department of Agriculture, Washington, DC. Available at: https://www.invasivespeciesinfo.gov/ (accessed 20 Sept 2020). 


\section{Annex 1: Species mentioned in this report with a link to the relevant ISC datasheet}

\begin{tabular}{|c|c|c|}
\hline Species name & $\begin{array}{l}\text { Common name(s) if } \\
\text { mentioned }\end{array}$ & URL for ISC datasheet \\
\hline Acacia decurrens & green wattle & https://www.cabi.org/isc/datasheet/2208 \\
\hline Acacia melanoxylon & Australian blackwood & https://www.cabi.org/isc/datasheet/2329 \\
\hline Achatina fulica & $\begin{array}{l}\text { giant African land } \\
\text { snail }\end{array}$ & https://www.cabi.org/isc/datasheet/2640 \\
\hline $\begin{array}{l}\text { Ageratum } \\
\text { conyzoides }\end{array}$ & billy goat weed & https://www.cabi.org/isc/datasheet/3572 \\
\hline Artemia & brine shrimp & https://www.cabi.org/isc/datasheet/103886 \\
\hline Asterias amurensis & $\begin{array}{l}\text { northern Pacific } \\
\text { seastar }\end{array}$ & https://www.cabi.org/isc/datasheet/92632 \\
\hline Austropuccinia psidii & myrtle rust & https://www.cabi.org/isc/datasheet/45846 \\
\hline Bactrocera dorsalis & Oriental fruit fly & https://www.cabi.org/isc/datasheet/17685 \\
\hline Bactrocera tryoni & Queensland fruit fly & https://www.cabi.org/isc/datasheet/17693 \\
\hline Bauhinia tomentosa & yellow bauhinia & https://www.cabi.org/isc/datasheet/8652 \\
\hline Bidens pilosa & blackjack & https://www.cabi.org/isc/datasheet/9148 \\
\hline $\begin{array}{l}\text { Candidatus } \\
\text { Liberibacter } \\
\text { solanacearum }\end{array}$ & zebra chip & https://www.cabi.org/isc/datasheet/109434 \\
\hline \multirow[t]{2}{*}{ Capsicum annuum } & bell pepper & https://www.cabi.org/isc/datasheet/15784 \\
\hline & $\begin{array}{l}\text { cassava mosaic } \\
\text { disease }\end{array}$ & https://www.cabi.org/isc/datasheet/2747 \\
\hline Cherax destructor & yabby & https://www.cabi.org/isc/datasheet/89134 \\
\hline $\begin{array}{l}\text { Chromolaena } \\
\text { odorata }\end{array}$ & Siam weed & https://www.cabi.org/isc/datasheet/23248 \\
\hline Clarias gariepinus & & https://www.cabi.org/isc/datasheet/88683 \\
\hline Cocos nucifera & coconut & https://www.cabi.org/isc/datasheet/11788 \\
\hline $\begin{array}{l}\text { Conopomorpha } \\
\text { cramerella }\end{array}$ & cocoa pod borer & https://www.cabi.org/isc/datasheet/7017 \\
\hline Cornu aspersum & common garden snail & https://www.cabi.org/isc/datasheet/26821 \\
\hline Cuscuta campestris & field dodder & https://www.cabi.org/isc/datasheet/17111 \\
\hline Cyathea cooperi & Australian tree fern & https://www.cabi.org/isc/datasheet/17261 \\
\hline $\begin{array}{l}\text { Cydalima } \\
\text { perspectalis }\end{array}$ & box tree moth & https://www.cabi.org/isc/datasheet/118433 \\
\hline $\begin{array}{l}\text { Cylindropuntia } \\
\text { fulgida }\end{array}$ & jumping cholla & https://www.cabi.org/isc/datasheet/37715 \\
\hline Drosophila suzukii & $\begin{array}{l}\text { spotted wing } \\
\text { drosophila }\end{array}$ & https://www.cabi.org/isc/datasheet/109283 \\
\hline
\end{tabular}




\begin{tabular}{|c|c|c|}
\hline Eleusine indica & goose grass & https://www.cabi.org/isc/datasheet/20675 \\
\hline Elodea canadensis & Canadian pondweed & https://www.cabi.org/isc/datasheet/20759 \\
\hline Erwinia amylovora & fireblight & https://www.cabi.org/isc/datasheet/21908 \\
\hline Fallopia japonica & Japanese knotweed & https://www.cabi.org/isc/datasheet/23875 \\
\hline $\begin{array}{l}\text { Fusarium oxysporum } \\
\text { f. sp. cubense }\end{array}$ & $\begin{array}{l}\text { Panama disease of } \\
\text { banana }\end{array}$ & https://www.cabi.org/isc/datasheet/24621 \\
\hline $\begin{array}{l}\text { Fusarium oxysporum } \\
\text { f. sp. cubense } \\
\text { tropical race } 4\end{array}$ & TR4 & https://www.cabi.org/isc/datasheet/59074053 \\
\hline $\begin{array}{l}\text { Globodera } \\
\text { rostochiensis }\end{array}$ & $\begin{array}{l}\text { yellow potato cyst } \\
\text { nematode }\end{array}$ & https://www.cabi.org/isc/datasheet/27034 \\
\hline Halyomorpha halys & $\begin{array}{l}\text { brown marmorated } \\
\text { stink bug }\end{array}$ & https://www.cabi.org/isc/datasheet/27377 \\
\hline Helianthus annuus & sunflower & https://www.cabi.org/isc/datasheet/26714 \\
\hline $\begin{array}{l}\text { Herpestes } \\
\text { auropunctatus }\end{array}$ & $\begin{array}{l}\text { small Indian } \\
\text { mongoose }\end{array}$ & https://www.cabi.org/isc/datasheet/80508 \\
\hline Heterotis niloticus & African bonytongue & https://www.cabi.org/isc/datasheet/80116 \\
\hline $\begin{array}{l}\text { Leifsonia xyli subsp. } \\
\text { xyli }\end{array}$ & $\begin{array}{l}\text { sugarcane ratoon } \\
\text { stunting disease }\end{array}$ & https://www.cabi.org/isc/datasheet/13712 \\
\hline Lepidiota stigma & sugarcane white grub & https://www.cabi.org/isc/datasheet/31422 \\
\hline \multirow[t]{2}{*}{$\begin{array}{l}\text { Litopenaeus } \\
\text { vannamei }\end{array}$} & $\begin{array}{l}\text { whiteleg shrimp; } \\
\text { Pacific white shrimp }\end{array}$ & https://www.cabi.org/isc/datasheet/71097 \\
\hline & $\begin{array}{l}\text { maize lethal necrosis } \\
\text { disease }\end{array}$ & https://www.cabi.org/isc/datasheet/119663 \\
\hline Mangifera indica & mango & https://www.cabi.org/isc/datasheet/34505 \\
\hline $\begin{array}{l}\text { Melaleuca } \\
\text { quinquenervia }\end{array}$ & paperbark tree & https://www.cabi.org/isc/datasheet/34348 \\
\hline Mnemiopsis leidyi & sea walnut & https://www.cabi.org/isc/datasheet/75102 \\
\hline Momordica charantia & bitter gourd & https://www.cabi.org/isc/datasheet/34678 \\
\hline Myocastor coypus & coypu & https://www.cabi.org/isc/datasheet/73537 \\
\hline Neogobius fluviatilis & monkey goby & https://www.cabi.org/isc/datasheet/115759 \\
\hline $\begin{array}{l}\text { Oreochromis } \\
\text { niloticus }\end{array}$ & Nile tilapia & https://www.cabi.org/isc/datasheet/72086 \\
\hline Oryza sativa & rice & https://www.cabi.org/isc/datasheet/37964 \\
\hline $\begin{array}{l}\text { Parthenium } \\
\text { hysterophorus }\end{array}$ & parthenium weed & https://www.cabi.org/isc/datasheet/45573 \\
\hline Pennisetum glaucum & pearl millet & https://www.cabi.org/isc/datasheet/39766 \\
\hline $\begin{array}{l}\text { Phthorimaea } \\
\text { absoluta }^{3}\end{array}$ & $\begin{array}{l}\text { South American } \\
\text { tomato pinworm }\end{array}$ & https://www.cabi.org/isc/datasheet/49260 \\
\hline
\end{tabular}

\footnotetext{
${ }^{3}$ Tuta absoluta was reclassified as Phthorimaea absoluta in Jan 2021.
} 


\begin{tabular}{|l|l|l|}
\hline $\begin{array}{l}\text { Pittosporum } \\
\text { undulatum }\end{array}$ & $\begin{array}{l}\text { Australian } \\
\text { cheesewood }\end{array}$ & https://www.cabi.org/isc/datasheet/45705 \\
\hline Plutella xylostella & diamondback moth & $\underline{\text { https://www.cabi.org/isc/datasheet/42318 }}$ \\
\hline Poecilia reticulata & guppy & $\underline{\text { https://www.cabi.org/isc/datasheet/68208 }}$ \\
\hline $\begin{array}{l}\text { Pomacea } \\
\text { canaliculata }\end{array}$ & golden apple snail & https://www.cabi.org/isc/datasheet/68490 \\
\hline $\begin{array}{l}\text { Pseudogymnoascus } \\
\text { destructans }\end{array}$ & $\begin{array}{l}\text { white-nose syndrome } \\
\text { fungus }\end{array}$ & $\underline{\text { https://www.cabi.org/isc/datasheet/119002 }}$ \\
\hline $\begin{array}{l}\text { Psidium guajava } \\
\text { Rosmarinus } \\
\text { officinalis }\end{array}$ & guava & $\underline{\text { https://www.cabi.org/isc/datasheet/45141 }}$ \\
\hline \begin{tabular}{l} 
Sciurus niger \\
\hline Sipha maydis
\end{tabular} & fox squirrel & $\underline{\text { https://www.cabi.org/isc/datasheet/47678 }}$ \\
\hline Sorghum bicolor & sorghum & $\underline{\text { https://www.cabi.org/isc/datasheet/50172 }}$ \\
\hline $\begin{array}{l}\text { Spodoptera } \\
\text { frugiperda }\end{array}$ & fall armyworm & $\underline{\text { https://www.cabi.org/isc/datasheet/50633 }}$ \\
\hline $\begin{array}{l}\text { Thaumetopoea } \\
\text { processionea }\end{array}$ & $\begin{array}{l}\text { oak processionary } \\
\text { moth }\end{array}$ & https://www.cabi.org/isc/datasheet/29810 \\
\hline Vespa velutina & Asian hornet & $\underline{\text { https://www.cabi.org/isc/datasheet/109164 }}$ \\
\hline Zingiber officinale & ginger & $\underline{\text { https://www.cabi.org/isc/datasheet/57537 }}$ \\
\hline
\end{tabular}




\section{Annex 2: 2017 Survey tool}

\section{ISC User Survey}

\section{CABI would like to find out more about you and your information requirements to help further develop}

the ISC. This questionnaire has 12 questions and should take you no more than 10 minutes to complete.

1. How often have you visited the ISC in the last 12 months?

$\bigcirc$ once $\bigcirc$ a few times $\bigcirc$ monthly $\bigcirc$ weekly $\bigcirc$ Daily

2. How useful is the Compendium to you? Please add feedback at the end of the survey

1 Not very useful $\bigcirc_{2} \bigcirc_{3}$ Moderately useful $\bigcirc_{4} \bigcirc 5$ very useful

3. Which of the following best describes your role when using the ISC?

\section{Researcher}

Land manager: Agriculture (crop)

Land manager: Animal production (incl. rangelands)

Land manager: Small-scale farmer

Land manager: Protected area

Land manager: Forestry

Land manager: Transport/infrastructure

Land manager: Recreation/tourism

Land manager: Urban

Land manager: Private land

Freshwater resource manager: Aquaculture

Freshwater resource manager: Protected area

Freshwater resource manager: Transport/ infrastructure

Freshwater resource manager:

Recreation/tourism

Marine resource manager: Fishery

Marine resource manager: Protected area

Marine resource manager:

Transport/infrastructure

Other (please specify)
Marine resource manager: Recreation/tourism

Policy maker

Plant protection officer

Animal health practitioner

Conservation officer

Quarantine officer

Pest controller

Risk assessor

Trader: Plants and plant products

Trader: Animals and animal products

Lecturer/teacher

Student

Extension worker

Trainer

Consultant/advisor

Librarian

Scientific publisher/database manager

Journalist

Amateur naturalist (incl. conservation volunteer, gardener, angler, etc.) 
4. What type of institution do you work in?

Government

University

Public research

Private research

Private company (non-research)

Other (please specify)
NGO/IGO

Development aid agency

I am self-employed

Voluntary group

5. Which area(s) of invasive species management are you primarily concerned with? Please select all that apply

O Research

O Policy development

O Horizon scanning, risk assessment, risk management (prevention)

O Forecasting/modelling (e.g. species establishment, spread and impact under various scenarios)

O Contingency planning/rapid response

O Identification/diagnosis

O Control/mitigation of impact

O Monitoring and surveillance

O Environmental impact assessment

O Socio-economic impact assessment

O Habitat restoration

O Resource allocation/cost-benefit analysis

O Teaching/training/outreach

O Raising awareness/stakeholder engagement

Other (please specify) 
6. Which geographic regions are of interest to you?
O Global
0 Regional ( $>1$ country)
O National
$0<$ Subnational (state/province level)>
$\mathrm{O}<$ Local $>$

Please specify (if you did not select Global)

7. Which taxonomic groups are of interest to you?
O All
O Plants
O Animals
O Microorganisms
O Only a few species interest me

Please specify (if you did not select All)

8. What priority would you give the following content enhancements?

New detailed datasheets on additional invasive species (commissioned from experts, peer reviewed, fully referenced, average $8 \mathrm{pp}$. A4)

Additional basic datasheets on invasive species (typically 1 paragraph overview, plus distribution and host data, max. 2 pp. A4)

Updating existing datasheets on invasive species

Alerts and news

$\bigcirc$

More abstracts of published literature

More full text of published literature

$\bigcirc$

More images 
Full text of grey/local literature/guides

$\bigcirc$

More links to specialist websites

More links to specialist organisations

$\bigcirc$

Contact details for experts

More information on hosts and vectors of plant and animal pathogens

0

More information on threatened species

More information on control options

$\bigcirc$

Information on national regulations (species and products)

More information on pathways of introduction

$\bigcirc$

More information on habitats at risk

Case studies (e.g. management experiences)

$\bigcirc$

Extension materials (e.g. guidance for farmers) at the regional level

Extension materials (e.g. guidance for farmers) at the national level

O

Other, please specify

9. What priority would you give the following functionality enhancements?

Low Medium High N/A

Improved navigation and filtering of content

Better advanced searching of invasive species datasheets (criterion-based)

Better advanced searching of bibliographic content

API for data retrieval

Enhanced mapping capability

Horizon scanning tools (identifying emerging threats)

Risk analysis tools 
Identification tools

Additional export formats

Facility to store and retrieve own notes about a species

Other (please specify)

10. From the previous two questions, please copy and paste the single enhancement you give the highest priority

11. Would you be willing to be contacted by CABI for further advice on developing the ISC?

No $\bigcirc$ Yes

If you answered yes, please provide your contact details

12. Additional feedback on the ISC

(If you wish to send further feedback at a later time, you can do this via the Contact button on the Home Page) 


\section{Annex 3: 2020 SurveyMonkey tool}

Use of the CABI Invasive Species Compendium (ISC)

The Invasive Species Compendium (ISC) is an encyclopaedic resource that brings together a wide range of different types of science-based information to support decision making in invasive species management (https://www.cabi.org/isc/about). This resource is available online for free. Objective: To assess the use of the Invasive Species Compendium in informing decisions and actions on management of invasive species in Kenya.

\section{Key Research Questions}

1. Are you aware of the CABI Invasive Species Compendium (ISC)? Yes/no

2. If you are aware of the CABI ISC, have you used the information on the CABI Invasive Species Compendium (ISC)? Yes/no

3. If you have used information on the CABI ISC, how are you using/have you used the information you get/got from the ISC?

4. Have you used/are using the information from the ISC to inform decisions, or actions around managing invasive species? Yes/no

5. Please, provide ways in which you are using, or have used the information from the ISC to inform decisions, or actions around managing invasive species. (Kindly explain, giving examples of how used, documents where used, etc.)

6. Please, give us feedback on usefulness of information on the ISC, or challenges you experience using the ISC.

7. Please, give your name and institution affiliated to, for further follow ups if needed.

Thank you, for taking your time to provide us with the information. 


\section{Annex 4: 2020 HotJar survey tool}

Invasive Species Compendium User Survey

We are currently carrying out a study to investigate how the ISC is used and what benefits it brings to its users. We are collecting stories about its impact, to help us demonstrate its value. We would like to ask four simple questions about your use.

Please complete the survey to win a free book on invasive species. The information from this survey will remain anonymous. Would you like to take part in the survey?

If yes, takes you to the questions below

$1 \quad$ How does use of the ISC help in your work? (tick all that apply)

- Provides quick access to relevant information

- Saves searching many different websites for information

- Provides accurate and up-to-date information

- Provides information not available elsewhere

- Presents information in a useful format for my needs

- Is easy to navigate to explore a topic

- Speeds up my research or (project) work/saves time

- Increases the quality of my research or (project) work

- I have not used the ISC for my work

- Other - FREE TEXT BOX (only appears when choose this option)

What have you used information or data from the ISC for? (tick all that apply)

- Research

- Policy development

- Risk assessment

- Prioritizing species for action

- Developing management plans

- Identifying invasive species

- Preparing extension materials

- Public awareness

- Journalism

- Teaching or training

- Writing proposals 
- Other (please include details below) FREE TEXT BOX (only appears when choose this option)

$3 \quad$ Please could you share an example of how you have used the ISC in your work? FREE TEXT BOX

- May we cite this example in a public report on the use and benefits of the ISC? (The information will remain anonymous, unless you wish to be cited.) YES/NO OPTION

- If yes, and are happy to be cited, please provide your details/name, role and organization

- May we contact you for follow-up questions on this example? YES/NO OPTION

- To enter our competition, please give a contact email LIMITED TEXT BOX

4 Thank you for this valuable information. Do you have any suggestions to improve the ISC that you would like to share?

FREE TEXT BOX 


\section{contact CABI}

\section{Africa}

Kenya

CABI, Canary Bird

673 Limuru Road, Muthaiga

PO Box 633-00621

Nairobi, Kenya

T: +254 (0)20 2271000/ 20

E: africa@cabi.org

\section{Ghana}

CABI, CSIR Campus

No. 6 Agostino Neto Road

Airport Residential Area

P. O. Box CT 8630, Cantonments

Accra, Ghana

T: +233 (0)302 797202

E: westafrica@cabi.org

Zambia

CABI, Southern Africa Centre

5834 Mwange Close

Kalundu

P.O. Box 37589

Lusaka, Zambia

T: +260967619665

E: westafrica@cabi.org

\section{Americas}

Brazil

CABI, UNESP-Fazenda Experimental Lageado, FEPAF (Escritorio da CABI)

Rua Dr. Jose Barbosa de Barros 1780

Fazenda Experimental Lageado

CEP:18.610-307

Botucatu, São Paulo, Brazil

T: +5514-38826300

E: y.colmenarez@cabi.org

Trinidad \& Tobago

CABI, Gordon Street, Curepe

Trinidad and Tobago

T: +18686457628

E: caribbeanLA@cabi.org

USA

CABI, 745 Atlantic Avenue

8th Floor, Boston,

MA 02111, USA

$\mathbf{T}:+1$ (617) 682-9015

E: cabi-nao@cabi.org

\section{Asia}

China

CABI, Beijing Representative Office

Internal Post Box 85

Chinese Academy of Agricultural Sciences

12 Zhongguancun Nandajie

Beijing 100081, China

T: +86 (0)10 82105692

E: china@cabi.org

India

CABI, 2nd Floor, CG Block,

NASC Complex, DP Shastri Marg

Opp. Todapur Village, PUSA

New Delhi - 110012, India

T: +91 (0)1125841906

E: cabi-india@cabi.org

Malaysia

CABI, PO Box 210,

43400 UPM Serdang

Selangor, Malaysia

T: +60 (0)3 89432921

E: cabisea@cabi.org

Pakistan

CABI, Opposite 1-A,

Data Gunj Baksh Road

Satellite Town, PO Box 8

Rawalpindi, Pakistan

T: +92 (0)519290132

E: sasia@cabi.org

\section{Europe}

Switzerland

CABI, Rue des Grillons 1

$\mathrm{CH}-2800$ Delémont, Switzerland

T: + 41 (0)32 4214870

E: europe-CH@cabi.org

UK

CABI, Nosworthy Way

Wallingford, Oxfordshire, OX10 8DE, UK

T: +44 (0)1491832111

E: corporate@cabi.org

CABI, Bakeham Lane

Egham, Surrey, TW20 9TY, UK

T: + 44 (0)1491 829080

E: cabieurope-uk@cabi.org

E:microbialservices@cabi.org 